LOQUENS 5(1)

January 2018, e050

eISSN 2386-2637

https://doi.org/10.3989/loquens.2018.050

\title{
Phrasing and nuclear configurations in authentic English-accented Spanish
}

\author{
Eva Estebas-Vilaplana ${ }^{1}$ and Beatriz Blecua ${ }^{2}$ \\ ${ }^{1}$ Universidad Nacional de Educación a Distancia (Spain) \\ eestebas@flog.uned.es ORCID: https://orcid.org/0000-0001-7866-0381 \\ beatriz.blecua@udg.edu ORCID: https://orcid.org/0000-0003-1619-0841
}

Submitted: 06/07/2017; Accepted: 11/12/2017; Published online: 18/09/2018

Citation / Cómo citar este artículo: Eva Estebas-Vilaplana and Beatriz Blecua. (2018). Phrasing and nuclear configurations in authentic English-accented Spanish. Loquens, 5(1), e050. https://doi.org/10.3989/loquens.2018.050

\begin{abstract}
This paper examines the differences in the division of intonation phrases and in the tonal structure of the nuclear configuration (i.e., the last pitch accent and the following boundary tone) in imitated and in authentic English-accented Spanish. The same Spanish text was read by four native speakers of American English, who produced the text with a real English foreign accent in Spanish, and six native speakers of Spanish, who read the text twice: in L1 Spanish and in fake English-accented Spanish. An auditory analysis of the data was carried out along with an inspection of the $f_{0}$ traces aligned with the spectrographic representation and the segmental string. The results showed that the Spanish speakers produce more intonation breaks when they imitate an English accent in Spanish than when they speak L1 Spanish. Furthermore, they adopt the typical tonal structure of Spanish final accents in their fake English-accented productions. The number of prosodic breaks in real and in imitated English-accented Spanish is similar. The nuclear configurations, on the other hand, present more variability and differ in the frequency of occurrence of some patterns. The high occurrence of the fall-rise pattern $\left(\mathrm{L}+\mathrm{H}^{*} \mathrm{LH} \%\right)$ and the presence of the high-fall contour $\left(\mathrm{L}+\mathrm{H}^{*} \mathrm{~L} \%\right)$ in the English productions may help discriminate an authentic English-accented Spanish from a fake one.
\end{abstract}

Keywords: imitated and authentic English-accented Spanish; phrasing; nuclear configuration; boundary tones.

RESUMEN: Fraseo y configuraciones nucleares en español con acento inglés auténtico e imitado.- El presente artículo analiza las diferencias en la división de las frases entonativas y en la estructura tonal de la configuración nuclear (i. e., el último acento tonal y el tono de frontera siguiente) en español con acento inglés imitado y auténtico. El mismo texto en español lo leyeron cuatro hablantes nativos de inglés americano, que produjeron el texto con acento extranjero inglés real, y seis hablantes nativos de español, que leyeron el texto dos veces: con su acento habitual de L1 y en español con acento inglés fingido. Se llevó a cabo un análisis auditivo de los datos junto con un análisis acústico de las curvas melódicas alineadas con la representación espectrográfica y con la cadena segmental. Los resultados mostraron que los hablantes españoles producen más pausas entonativas cuando imitan el acento inglés. Además, en acento inglés fingido adoptan la estructura tonal típica de las configuraciones nucleares del español. El número de pausas prosódicas en las producciones con acento inglés real e imitado es similar. Por otro lado, las configuraciones nucleares presentan mayor variación y se diferencian en la frecuencia de aparición de algunos patrones. La alta frecuencia del patrón descendente-ascendente $\left(\mathrm{L}+\mathrm{H}^{*} \mathrm{LH} \%\right)$ y la presencia de un tono circunflejo $\left(\mathrm{L}+\mathrm{H}^{*} \mathrm{~L} \%\right)$ en las producciones de los anglófonos podría ayudar a discriminar una producción en español con acento inglés auténtico de una con acento fingido.

Palabras clave: español con acento inglés imitado y auténtico; fraseo; configuración nuclear; tonos de frontera.

Copyright: (C) 2018 CSIC. This is an open-access article distributed under the terms of the Creative Commons Attribution 4.0 International (CC BY 4.0) License. 


\section{INTRODUCTION}

Forensic Phonetics is the branch of Legal Linguistics that examines the characteristics of human speech for legal purposes. It covers a variety of issues, such as the identification of the speaker's phonetic profile (e.g., sex, social class, dialectal variety, etc.) or the comparison between known and unknown speech samples so as to help identify a particular speaker.

However, the identification of a speaker through his voice tends to be a difficult task and a great challenge for Forensic Phonetics since it is common amongst criminals to voluntarily disguise their accent. According to Masthoff (1996), when an individual knows he is being recorded or learns that his voice is examined for investigation purposes, he alters his accent in $52 \%$ of the cases.

There are many ways to modify one's voice, both electronically and physiologically (Rodman, 1998). The non-electronic or physiological disguise is frequently encountered in cases of kidnapping, extortions, or threatening telephone calls. Criminals usually alter their voices by modifying their phonation, such as by means of creaky voice or falsetto voice (Künzel, 2000), the production of prosodic features $\left(f_{0}\right.$, tempo), and the shape of the oral resonances, namely, they pinch their noses or use objects to block their mouth or the headphones. Criminals can also change voluntarily the segmental and suprasegmental features of their speech so as they could be associated with a foreign accent or a dialectal variety.

This study deals with this last type of voice alteration, that is, the imitation of a foreign accent. In particular, it examines the production of imitated English-accented Spanish produced by L1 Spanish speakers as opposed to real English-accented Spanish produced by L1 English speakers.

Even though most studies on fake foreign accent agree in that there are certain cues in the imitated speech that might help identify the fake productions (Markham, 1999; Storey, 1996; Tate, 1979), the distinction between an authentic and an imitated foreign accent is not always an easy task. So far, experimental studies on fake foreign accents have focused both on their production and on their perception, that is, they analyze the capacity of the speakers to imitate foreign or regional accents (Neuhauser, 2008), as well as their ability to detect an authentic foreign accent and discriminate it from a fake one (Gibson, Blecua, \& Cicres, 2017; Neuhauser \& Simpson, 2007; Schoonmaker-Gates, 2012).

There are not many studies on the imitation of a foreign accent in Spanish. From a perceptual perspective, Schoonmaker-Gates (2012) analyzed the degree of foreign accent perception based on the VOT values in Spanish plosives produced by L1 Spanish speakers and L1 American English speakers learning L2 Spanish. She concluded that native and non-native speakers look at different acoustic cues in their perception of accents.

Gibson, Blecua, and Cicres (2017) compared the perception of Spanish vowels produced in L1 Spanish, and in real and in fake English-accented Spanish. The stimuli included only the vowels in stressed syllables. One native speaker of Spanish read a text twice in L1 Spanish and in imitated English-accented Spanish. One American English speaker read the same text with real Englishaccented Spanish. Two groups of judges (native speakers of L1 Spanish and L1 English) were asked to classify the stimuli in three categories: L1 Spanish, imitated Englishaccented Spanish, and real English-accented Spanish. Both groups of judges correctly identified the stimuli in L1 Spanish. However, only the English speakers were able to discriminate a fake accent from an imitated one. The Spanish speakers could not distinguish the two accents, even though both speech samples showed significant acoustic differences. These results are in line with those of Schoonmaker-Gates (2012), and suggest that native and non-native speakers perceive foreign accents differently.

From a production perspective, Cicres and Fernández Trinidad (2017) compared the acoustic characteristics of fricative sounds produced by native Spanish speakers in their L1 and in imitated English-accented Spanish. The results showed significant differences in the production of $/ \mathrm{s} /$ and $/ \theta /$.

As far as suprasegmental features are concerned, Estebas-Vilaplana (2017a) examined the intonation patterns of fixed enumerations (with a confined number of elements, such as the days of the week) and variable enumerations (with an unlimited number of components) in real and in fake English-accented Spanish. The results of this study showed that in an imitated accent, Spanish speakers produced fixed enumerations (commonly pronounced with a sustained tone in the non-final elements) with the typical rising intonation pattern of variable enumerations, showing an unexpected usage of certain $f_{0}$ patterns in the fake accent.

Estebas-Vilaplana (2017b) analyzed the production of English stress-timed rhythm and the weak vowel schwa by Spanish students of English when they speak L2 English and L1 Spanish with an imitated English accent. The results showed that the Spanish speakers' productions of English rhythm and the schwa are closer to real English in the imitation scenario than in the L2 speech, indicating that rhythm seems to be a relevant feature for a good imitation of English pronunciation with positive effects on the production of the weak vowel schwa.

The present paper analyzes two other prosodic features in imitated and in authentic English-accented Spanish, namely, the division of a text into intonation phrases and the intonational patterns at the end of those phrases. The aim of this study is twofold: 1) to examine the location of prosodic breaks and the tonal structure of the nuclear configurations in imitated English-accented Spanish (IEAS), and 2) to compare the results with both L1 Spanish and authentic English-accented Spanish (AEAS).

\section{EXPERIMENTAL PROCEDURE}

\subsection{The materials}

The materials used in this study consist in a phonetically balanced text in Spanish that was read by 4 native speakers of American English and 6 native speakers of Spanish. 
The text was obtained from Bruyninckx, Harmegnies, Llisterri, and Poch-Olivé (1994). All the sentences in the text are declarative sentences.

The informants were given the text before the recording, so that they could prepare it in advance for about 5 minutes. The Spanish native speakers had to read the text twice. For the first recording, they were instructed to read it imitating a typical English accent in Spanish. In the second recording, they read it in their normal L1 Spanish accent. The English speakers read the text once, with their real English-accented Spanish.

Thus, the corpus comprised 4 recordings in authentic English-accented Spanish (AEAS), 6 recordings in L1 Spanish and 6 recordings in fake or imitated Englishaccented Spanish (IEAS).

The recordings of the native Spanish speakers were carried out in a soundproof booth at the Phonetics Laboratory at the University of Girona, with an AudioTechnica AT2050 microphone and a Focusrite Scarlett $2 \mathrm{i} 2$ digitizer card. The American English informants were recorded in the Speech Laboratory of the University of Navarra, under the same conditions.

\subsection{The informants}

The informants were 3 male and 3 female native speakers of Peninsular Spanish, without a particularly regional accent, and 2 male and 2 female native speakers of North American English, all aged between 20 and 40 and with higher education.

The Spanish-speaking informants had an intermediate level of English, whereas the American English speakers had an intermediate level of Spanish.

The Spanish speakers are identified as SS1-6 and the English speakers as ES1-4.

\subsection{Data analysis}

Auditory and acoustic analyses of the data were performed. For these analyses, the text was divided into 15 phrases, which allowed us to carry out a detailed prosodic inspection of the $f_{0}$ contours. Each of these phrases ended with a prosodic break in $100 \%$ of the productions of all speakers (both Spanish and English) in all reading conditions. However, as detailed in Section 3, these phrases could be further subdivided into other prosodic domains depending on the speaker's choice. The initial division of the text into phrases for its prosodic analysis is presented in (1).

(1)

01. El joyero Federico Vanero

02. ha sido condenado por la Audiencia de Santander

03. a ocho meses de arresto mayor|

04. y cincuenta mil pesetas de multa

05. por un delito de compra de objetos robados. |

06. La vista oral se celebró el miércoles pasado |

07. y, durante ella, |
08. uno de los fiscales, Carlos Valcárcel,

09. pidió para el joyero tres años de prisión menor |

10. y una multa de cincuenta mil pesetas.|

11. Gracias a las revelaciones de Vanero |

12. de hace dos años y medio |

13. se llegó a descubrir la existencia de una sospechosa mafia policial en España, |

14. parte de la cual se vio envuelta en el llamado |

15. “caso el Nani”. 1 |

Each phrase was stored on a separate audio file. Overall 180 phrases were analyzed for the 6 Spanish speakers (90 produced in L1 Spanish and 90 in IEAS) and 60 phrases for the 4 English speakers (all of them produced in AEAS). The prosodic analysis of the corpus was done by means of Praat (version 6.0.33). For each audio file, a textgrid was created with three tiers with the following information: 1) the syllable division of the phrase (in spelling), 2) the presence of a prosodic break, and 3 ) the annotation of the tonal categories (pitch accent and boundary tone) for the final $f_{0}$ movement in the phrase.

For this study, no distinction was made between levels of prosodic phrasing, that is, the presence of a prosodic break was equally transcribed irrespective of being a major break (or intonation phrase) or a minor break (or intermediate phrase). In the acoustic analysis, all breaks were marked as 'PB' (prosodic break). The main cue to identify a prosodic break was the presence of a boundary tone. In some cases, this tone was accompanied by a pause. False breaks, such as stammering or disfluencies, were excluded from the analysis.

The prosodic annotation of the final configuration of the pitch contours followed the $\mathrm{Sp}$ ToBI system conventions, firstly proposed by Beckman, Díaz-Campos, McGory, and Morgan (2002) and further revised in Estebas-Vilaplana and Prieto Vives (2008), Hualde and Prieto (2015), and Estebas-Vilaplana, Gutiérrez, Vizcaíno, and Cabrera (2015). Sp_ToBI describes intonation by means of two tones: $(\mathrm{H}) \overline{i g h}$ and (L)ow. Pitch accents are associated with stressed syllables and boundary tones with the right edge of the intonation phrase. Sp_ToBI includes six pitch accents, which can be monotonal $\left(\mathrm{L}^{*}, \mathrm{H}^{*}\right)$ or bitonal $\left(\mathrm{L}+\mathrm{H}^{*}, \mathrm{~L}+>\mathrm{H}^{*}, \mathrm{~L}^{*}+\mathrm{H}, \mathrm{H}+\mathrm{L}^{*}\right)$. In the first version of the Sp_ToBI system (Beckman et al., 2002), boundary tones were only monotonal, such as $\mathrm{L} \%$ and $\mathrm{H} \%$. A mid boundary tone ( $\mathrm{M} \%$ ) was also incorporated to account for those final pitch movements where the $f_{0}$ rises or falls into a mid-pitch. More recent revisions of the system (Estebas-Vilaplana \&

\footnotetext{
1 The jeweler Federico Vanero has been sentenced by the Court of Santander|to eight months in prison $\mid$ and a fine of fifty thousand pesetas | for the crime of buying stolen goods. | The oral hearing was held last Wednesday and, during the session, one of the prosecutors, Carlos Valcárcel,| requested for the jeweler three years of simple imprisonment | and a fine of fifty thousand pesetas. Due to Vanero's report two and a half years ago, $\mid$ the existence of a suspicious police mafia in Spain was disclosed, | part of which was involved in the so-called | "caso el Nani".
} 
Prieto Vives, 2008) also included bitonal boundary tones to describe final complex pitch movements $(\mathrm{LH} \%$, $\mathrm{HL} \%, \mathrm{HH} \%$ ). The last versions of the Sp_ToBI system substitute the $\mathrm{M} \%$ notation for a final mid pitch by $! \mathrm{H} \%$ (Hualde \& Prieto, 2015) and use $=\%$ to indicate a sustained pitch (Estebas-Vilaplana et al., 2015).

In this paper, only the final configuration of the $f_{0}$ contours was analyzed. As stated in Face (2007), even though the pre-nuclear component obviously contributes to the creation of meaning, it is the nuclear configuration which is usually responsible for the final semantic interpretation of the sentence. Furthermore, most of the speakers divided the text into several short phrases made up of a pitch accent and a boundary tone. Thus, the analysis of the pre-nuclear accents was left for further research.

The Sp ToBI conventions were used to examine not only the productions of the Spanish speakers (both in L1 Spanish and in IEAS) but also those of the English speakers in AEAS. Even though there might be differences in the intonation patterns produced by these two groups of speakers, it was considered necessary to annotate the contours with the same labelling system so as to facilitate the comparison between the two languages. Since

Table 1: Sp ToBI notation conventions for different final pitch patterns.

\begin{tabular}{ll}
\hline Sp_ToBI & Pitch pattern \\
\hline $\mathrm{L}^{*} \mathrm{~L} \%$ & Low-fall \\
$(\mathrm{L})+\mathrm{H}^{*} \mathrm{~L} \%$ & High-fall \\
$(\mathrm{L})+\mathrm{H}^{*} \mathrm{H} \%$ & Rise \\
$(\mathrm{L})+\mathrm{H}^{*} ! \mathrm{H} \%$ & Fall-to-mid \\
$(\mathrm{L})+\mathrm{H}^{*} \mathrm{LH} \%$ & Fall-rise \\
$*=\%$ & Sustained \\
\hline
\end{tabular}

all the data were produced in Spanish, the Sp ToBI system was considered the most suitable labelling tool for the prosodic transcriptions. Furthermore, the Sp_ToBI annotation conventions used in this study could account for the majority of the final pitch movements found in the data of both groups of speakers. Table 1 includes the Sp ToBI labels used in this study along with the pitch patterns they describe. Note that the annotation for sustained pitch $(*=\%)$ does not include a specific final pitch accent. As proposed in Estebas-Vilplana et al. (2015), the $=\%$ boundary tone represents a phonological entity with an underspecified pitch height and whose phonological nature could be described as 'remain sustained'. Thus, it will keep the height of the final pitch accent, either $\mathrm{L}^{*}, \mathrm{H}^{*}$, or $! \mathrm{H}^{*}$ (see below for the meaning of $\left.! \mathrm{H}^{*}\right)$. The brackets in some of the bitonal accents in Table 1 indicate that sometimes the $\mathrm{L}$ is not clearly produced, most probably due to the presence of two consecutive $\mathrm{L}+\mathrm{H}^{*}$ tones with no time to reach the second $\mathrm{L}$ target. Furthermore, in some cases the high tone in the bitonal pitch accents $\left(\mathrm{L}+\mathrm{H}^{*}\right)$ can be produced with downstep $\left(\mathrm{L}+! \mathrm{H}^{*}\right)$, that is, with an $f_{0}$ peak that is lower than a preceding $f_{0}$ peak in the same phrase. Downstep is indicated by means of the diacritic ! before the $\mathrm{H}^{*}$ accent. Downstep is not marked in the tones presented in Table 1, but it will be indicated in the acoustic analysis when applicable.

The annotation process was performed by two trained transcribers. Each transcriber generated a time-aligned display of the speech signal (waveform and $f_{0}$ curve overlapped with a spectrographic representation of the phrase) and relied on auditory and visual information to annotate the intonation patterns. The annotations of the two transcribers were contrasted in order to reach a consensus on the final labelling. An example of the analysis is provided in Figure 1 for the utterance La vista oral se celebró el miércoles pasado produced by speaker SS6. Microintonation features were excluded from the phonological

FIGURE 1: Example of the acoustic analysis (waveform, $f_{0}$ curve, and spectrographic representation) for the utterance La vista oral se celebró el miércoles pasado produced by speaker SS6 in L1 Spanish. The three layers show: syllable division, prosodic boundaries (PB), and the tonal annotation of the nuclear configuration.

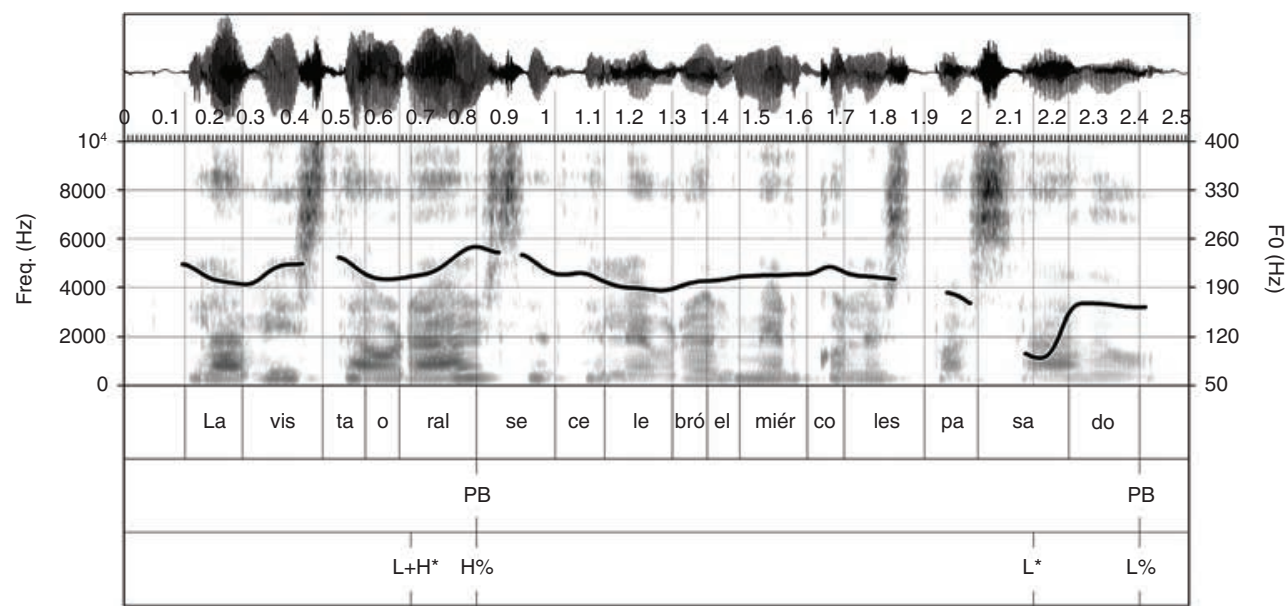


analysis. For example, in Figure 1 the abrupt lowering of $f_{0}$ at the beginning of the syllable $-s a$ - is due to the effect of the fricative. Thus, the $\mathrm{L}^{*}$ pitch accent is not used to indicate this sudden $f_{0}$ drop but it describes the progressive falling contour typical of unmarked statements in Spanish.

Finally, a statistical analysis of the data was carried out to compare the proportion (or frequency of occurrence) of the final tonal configurations in the three samples of speech (L1 Spanish, IEAS, and AEAS). The statistical analysis was performed using a Chi-square test and the results of contingency tables. The adjusted residual values were calculated, which have a mean of 0 and a standard deviation of 1 . The values that are higher than 1.96 and lower than -1.96 indicate that there is a significant lack of proportion in favor of one variant or the other. IBM SPSS Statistics 21 was used for this purpose.

\section{RESULTS}

First, the results of the Spanish speakers both in L1 Spanish and in imitated English-accented Spanish (IEAS) are presented. Then, the productions of the English speakers in authentic English-accented Spanish (AEAS) are examined. For each group of speakers, the results are divided into two sections: 1) phrasing and 2) the tonal analysis of the nuclear configuration (last pitch accent and boundary tone).

\subsection{Spanish speakers}

\subsubsection{Phrasing}

The presence of a prosodic break, signaled by a boundary tone and an optional pause, was analyzed for the two productions of the six Spanish speakers, namely, in L1 Spanish and in IEAS. The text in (2) shows the places where a prosodic break was produced in L1 Spanish and the percentage of occurrence.

\section{(2) L1 Spanish}

01. El joyero (33.3\%) | Federico Vanero (100\%) |

02. ha sido condenado (33.3\%) | por la Audiencia de Santander $(100 \%)$

03. a ocho meses de arresto mayor (100\%)

04. y cincuenta mil pesetas de multa $(100 \%)$

05. por un delito de compra de objetos robados. $(100 \%)$

06. La vista oral $(83.3 \%) \mid$ se celebró el miércoles pasado $(100 \%)$

07. y, durante ella, (100\%)

08. uno de los fiscales, $(100 \%) \mid$ Carlos Valcárcel, $(100 \%)$

09. pidió para el joyero $(66.6 \%) \mid$ tres años de prisión menor $(100 \%)$

10. y una multa de cincuenta mil pesetas. $(100 \%)$ |

11. Gracias a las revelaciones de Vanero $(100 \%)$

12. de hace dos años $(66.6 \%) \mid$ y medio $(100 \%) \mid$
13. se llegó a descubrir la existencia de una sospechosa mafia policial en España, $(100 \%)$

14. parte de la cual $(83.3 \%) \mid$ se vio envuelta en el llamado $(100 \%)$

15. “caso $(66.6 \%) \mid$ el Nani”. (100\%)|

The text in (3) shows the places where a prosodic break was produced in IEAS and the percentage of occurrence. The phrases marked in bold indicate that there was no break in this position when the text was read in L1 Spanish, whereas those marked in bold and italics show that there has been an increase in the number of prosodic breaks in this position. There are no cases with a break in L1 Spanish and no break or less occurrences of it in IEAS.

(3) Imitated English-accented Spanish (IEAS)

01. El joyero (66.6\%) $\mid$ Federico Vanero (100\%)

02. ha sido condenado (83.3\%) | por la Audiencia

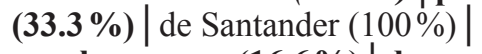

03. a ocho meses (16.6\%)| de arresto (33.3\%) | mayor (100\%)|

04. y cincuenta mil $(33.3 \%) \mid$ pesetas $(50 \%) \mid$ de multa $(100 \%)$

05. por un delito de compra $(83.3 \%) \mid$ de objetos (16.6\%) | robados. (100\%)|

06. La vista oral (100\%) | se celebró (66.6\%)| el miércoles pasado $(100 \%) \mid$

07. $\mathrm{y}$, durante ella, $(100 \%)$

08. uno de los fiscales, (100\%) $\mid$ Carlos Valcárcel, $(100 \%)$

09. pidió para el joyero (100\%)|tres años (16.6\%)| de prisión (16.6\%) | menor (100\%)|

10. y una multa $(\mathbf{5 0} \%) \mid$ de cincuenta mil pesetas. $(100 \%)$

11. Gracias a las revelaciones de Vanero (100\%)

12. de hace dos años (83.3\%) | y medio (100\%)

13. se llegó a descubrir $(50 \%) \mid$ la existencia $(83.3 \%) \mid$ de una sospechosa mafia $(83.3 \%)$ | policial (83.3\%) | en España, (100\%)|

14. parte de la cual $(83.3 \%) \mid$ se vio (16.6\%) | envuelta (83.3\%) | en el llamado (100\%)|

15. “caso $(66.6 \%)$ el Nani". (100\%)

The analysis of phrasing in the two texts shows that there are more instances of prosodic breaks in the IEAS reading than in the L1 Spanish reading. Figures 2 and 3 show the same speech chunk (la existencia de una sospechosa mafia policial en España) produced by SS1 in L1 Spanish and in IEAS respectively. Whereas in L1 Spanish the utterance is produced with one intonation unit and thus, it only contains a prosodic break (PB) at the end of the phrase, in IEAS the same structure is produced with four intonation phrases (la existencia) de una sospechosa mafia|policial|en España).

The higher number of intonation breaks in IEAS is confirmed with the results provided in Table 2, which shows the individual and the total number of occurrences of prosodic breaks produced by the Spanish speakers in 
FigURE 2: Example of the utterance la existencia de una sospechosa mafia policial en España produced with one phrase by SS1 in L1 Spanish.

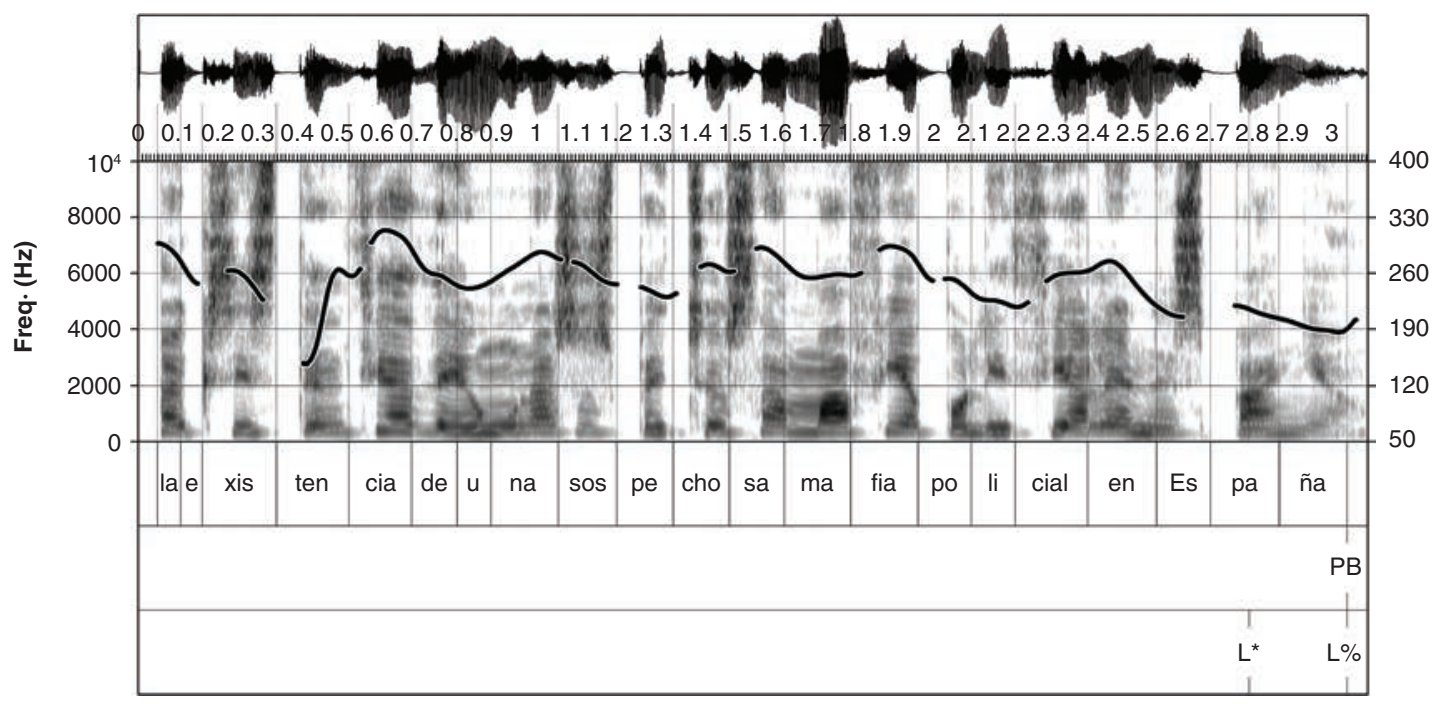

FIGURE 3: Example of the utterance la existencia $\mid$ de una sospechosa mafia $\mid$ policial | en España produced with four prosodic breaks by SS1 in in imitated English- accented Spanish (IEAS).

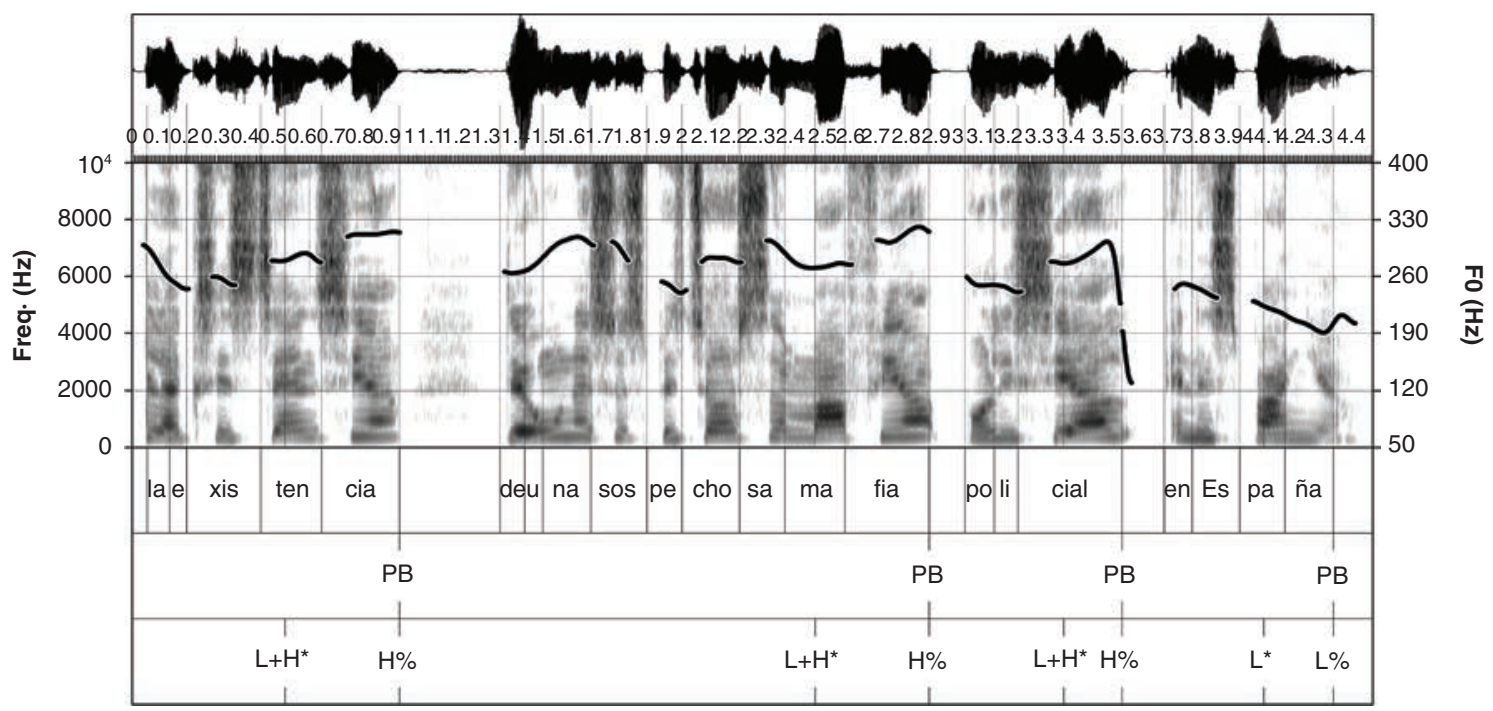

the two reading conditions. The mean values indicate an average of 22 breaks in L1 Spanish as opposed to 30 breaks in IEAS, showing an overall increase of $27 \%$ of prosodic breaks in IEAS.

Table 3 includes the percentage of agreement and disagreement in the production of prosodic breaks in L1 Spanish and in IEAS, that is, it exhibits the cases where all speakers produced a prosodic break versus those cases where only some of them produced a break. As far as the L1 Spanish reading is concerned, the results show that in $69.5 \%$ of the cases all speakers produced a prosodic break, whereas in $30.5 \%$ of the cases only some speakers produced a break. In IEAS, all speakers produced a prosodic break in $45 \%$ of the cases, whereas in $55 \%$ of the cases only some speakers produced a break. These results indicate that there is a greater variability in the production of prosodic breaks in IEAS than in L1 Spanish. As presented in Table 2, despite having a greater number of overall prosodic breaks in IEAS (180 breaks) than in L1 Spanish (132 breaks), the percentage of total coincidence in the production of prosodic boundaries is greater in L1 Spanish (with $69.5 \%$ of complete agreement in the location of a break) than in IEAS (with $45 \%$ of complete agreement in the location of a break). This indicates that 
a fake reading not only prompts the occurrence of more breaks but also shows more variability in their location.

\subsubsection{Final tone configurations}

In order to analyze the final pitch movements, utterances have been divided into two kinds: 1) those that convey unfinished information and 2) those that indicate that the message is complete. This distinction has been used since Navarro Tomás (1974 [1944]) to describe the intonation patterns of declarative sentences and has been incorporated in many other studies of Spanish intonation (Alcina \&

Table 2: Individual and total number and mean value of prosodic breaks produced by the Spanish speakers (SS) in the two readings of the text: in L1 Spanish and in imitated English- accented Spanish (IEAS).

\begin{tabular}{lcc}
\hline & \multicolumn{2}{c}{ Number of prosodic breaks } \\
\cline { 2 - 3 } Speakers & L1 Spanish & IEAS \\
\hline SS1 & 23 & 33 \\
SS2 & 24 & 32 \\
SS3 & 23 & 33 \\
SS4 & 21 & 29 \\
SS5 & 21 & 23 \\
SS6 & 20 & 30 \\
Total & 132 & 180 \\
Mean & 22 & 30 \\
\hline
\end{tabular}

Table 3: Percentage of (dis)agreement in the presence of a prosodic break (PB) in L1 Spanish and in imitated English-accented Spanish (IEAS).

\begin{tabular}{lcc}
\hline & L1 Spanish & IEAS \\
\hline \% of agreement in the location of PB & 69.5 & 45 \\
\% of disagreement in the location of PB & 30.5 & 55 \\
\hline
\end{tabular}

Blecua, 1975; Quilis, 1993, among others). According to Navarro Tomás, Spanish declarative sentences are made up of two parts, namely, the protasis, which indicates that the sentence has not yet finished and there is more information to follow, and the apodosis, where the information is final or complete. Each part is usually associated with an intonation unit, as in Los hijos de Elvira (protasis) / son muy simpáticos (apodosis) ("Elvira's children / are very nice"). However, there might be cases in which the protasis includes more than one intonation unit.

The tone inventory proposed by Navarro Tomás (1974 [1944]) to describe the pitch patterns of declarative sentences is closely linked to the part of the utterance they are associated with. The apodosis tends to end with a cadencia or a low-fall tone ( $\left.\mathrm{L}^{*} \mathrm{~L} \%\right)$. In some cases, it may be associated with a tono circunflejo or high-fall ( $\left.\mathrm{L}+\mathrm{H}^{*} \mathrm{~L} \%\right)$, which tends to convey an emphatic statement. The intonation units in the protasis can have different endings, such as an anticadencia or rise $\left((\mathrm{L})+\mathrm{H}^{*} \mathrm{H} \%\right)$, a semicadencia or fall-to-mid tone $\left((\mathrm{L})+\mathrm{H}^{*} ! \mathrm{H} \%\right)$, and a tono suspensivo or sustained tone $(*=\%)$. More recent studies of Spanish intonation (Estebas-Vilaplana et al., 2015) have shown that a fall-rise pattern $\left((\mathrm{L})+\mathrm{H}^{*} \mathrm{LH} \%\right)$ is also common in the protasis part.

Table 4 includes the number of occurrences of the final tonal configurations produced by the six Spanish speakers in L1 Spanish. The shaded boxes correspond to the intonation patterns expected in the apodosis (or phrases that indicate complete information) and the white boxes are the tonal configurations typical of the protasis (or phrases that indicate non-finality).

The text includes four phrases in the apodosis position, which are reproduced in (4). The rest of phrases belong to the protasis.

(4) Phrases in the apodosis

05. (...) por un delito de compra de objetos robados.

06. (...) se celebró el miércoles pasado. |

10. (...) y una multa de cincuenta mil pesetas. |

15. (...) "caso el Nani”.

Table 4: Number of occurrences of the final tonal configurations produced by the six Spanish speakers in L1 Spanish in the protasis and in the apodosis positions.

\begin{tabular}{|c|c|c|c|c|c|c|c|}
\hline \multirow[b]{3}{*}{ Sp } & \multicolumn{7}{|c|}{ Number of occurrences of the final tonal configurations in L1 Spanish } \\
\hline & \multicolumn{5}{|c|}{ Protasis } & \multicolumn{2}{|c|}{ Apodosis } \\
\hline & $(\mathrm{L})+\mathbf{H} * \mathbf{H} \%$ & $(\mathrm{~L})+\mathbf{H} * ! \mathbf{H} \%$ & $(\mathbf{L})+\mathbf{H} * \mathbf{L H} \%$ & $*=\%$ & $\mathbf{L} * \mathbf{L} \%$ & $\mathbf{L} * \mathbf{L} \%$ & $(\mathbf{L})+\mathbf{H} * \mathbf{L} \%$ \\
\hline SS1 & 17 & - & 1 & - & 1 & 4 & - \\
\hline SS2 & 19 & - & - & - & 1 & 4 & - \\
\hline SS3 & 13 & 5 & - & - & 1 & 4 & - \\
\hline SS4 & 15 & - & - & 2 & - & 4 & - \\
\hline SS5 & 16 & 1 & - & - & - & 4 & - \\
\hline SS6 & 13 & 1 & 1 & - & 1 & 4 & - \\
\hline All & 93 & 7 & 2 & 2 & 4 & 24 & - \\
\hline
\end{tabular}


All speakers produced the four phrases in the apodosis with the expected L* L\% configuration. An example is provided in Figure 1 above. No speaker used the circumflex tone $\left(\mathrm{L}+\mathrm{H}^{*} \mathrm{~L} \%\right)$, which, given its emphatic nuance, it is more likely to be found in spontaneous speech. Other studies of Spanish intonation based on a read corpus, such as Navarro Tomás (1974 [1944]), de-la-Mota and Rodero (2011), and Estebas-Vilaplana et al. (2015), also found the $\mathrm{L}^{*} \mathrm{~L} \%$ as the unmarked tonal configuration in the apodosis, used to convey a finished statement.

The most recurrent tonal configuration in the protasis found in the L1 Spanish data involves a rising contour ((L) $\left.+\mathrm{H}^{*} \mathrm{H} \%\right)$, as observed in Figure 1. A few instances of a final fall-to-mid tone $\left((\mathrm{L})+\mathrm{H}^{*} ! \mathrm{H} \%\right)$ were also found in the L1 Spanish data. An example is provided in Figure 4 for the utterance la existencia de una sospechosa mafia policial|en España produced by speaker SS4 in L1 Spanish. The utterance shows a case of fall-to-mid tone $\left(\mathrm{L}+\mathrm{H}^{*} ! \mathrm{H} \%\right)$ at the end of the first phrase and a rising tone $\left(\mathrm{L}+\mathrm{H}^{*} \mathrm{H} \%\right)$ at the end of the second phrase.

A minority of cases presented a final fall-rise $\left(\mathrm{L}+\mathrm{H}^{*} \mathrm{LH} \%\right)$ or a sustained tone $(*=\%)$. Figure 5 shows the utterance $y$ durante ella $\mid$ uno de los fiscales produced by SS6 in L1 Spanish with a final fall-rise in the first phrase $\left(\mathrm{L}+\mathrm{H}^{*} \mathrm{LH} \%\right)$ and a final rise $\left(\mathrm{L}+\mathrm{H}^{*} \mathrm{H} \%\right)$ in the second phrase. Figure 6 shows the utterance $y$ cincuenta mil pesetas de multa produced by SS4 with a final sustained pitch that maintains the high pitch of the $\mathrm{L}+\mathrm{H}^{*}$ pitch accent $\left(\mathrm{L}+\mathrm{H}^{*}=\%\right)$.

Figure 4: Example of a fall-to-mid tone $\left(\mathrm{L}+\mathrm{H}^{*} ! \mathrm{H}^{\%} \%\right)$ and a rising tone $\left(\mathrm{L}+\mathrm{H}^{*} \mathrm{H} \%\right)$ for the utterance la existencia de una sospechosa mafia policial| en España produced by SS4 in L1 Spanish.

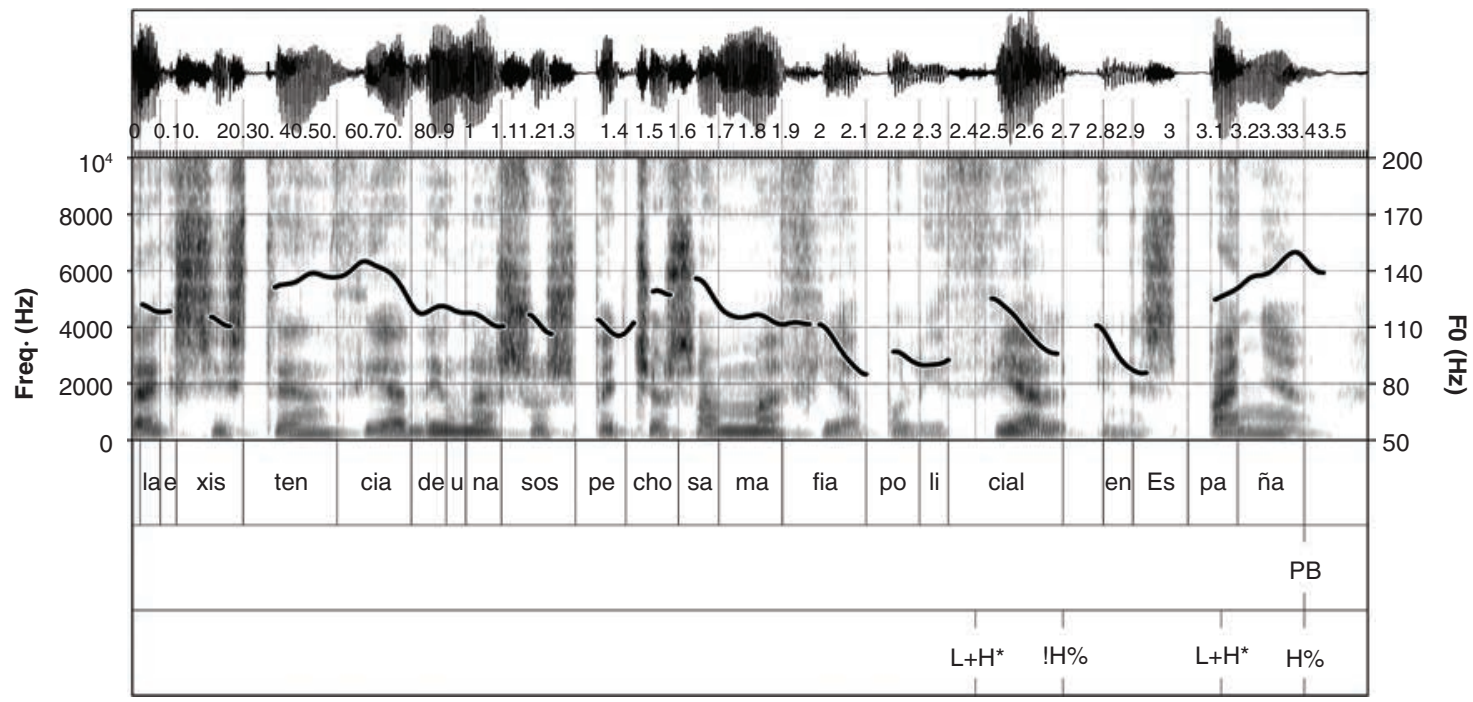

Figure 5: Example of final fall-rise $\left(\mathrm{L}+\mathrm{H}^{*} \mathrm{LH} \%\right)$ and a rise $\left(\mathrm{L}+\mathrm{H}^{*} \mathrm{H} \%\right)$ at the end of the two phrases of the utterance $y$ durante ella $\mid$ uno de los fiscales $\mid$ produced by SS6 in L1 Spanish.

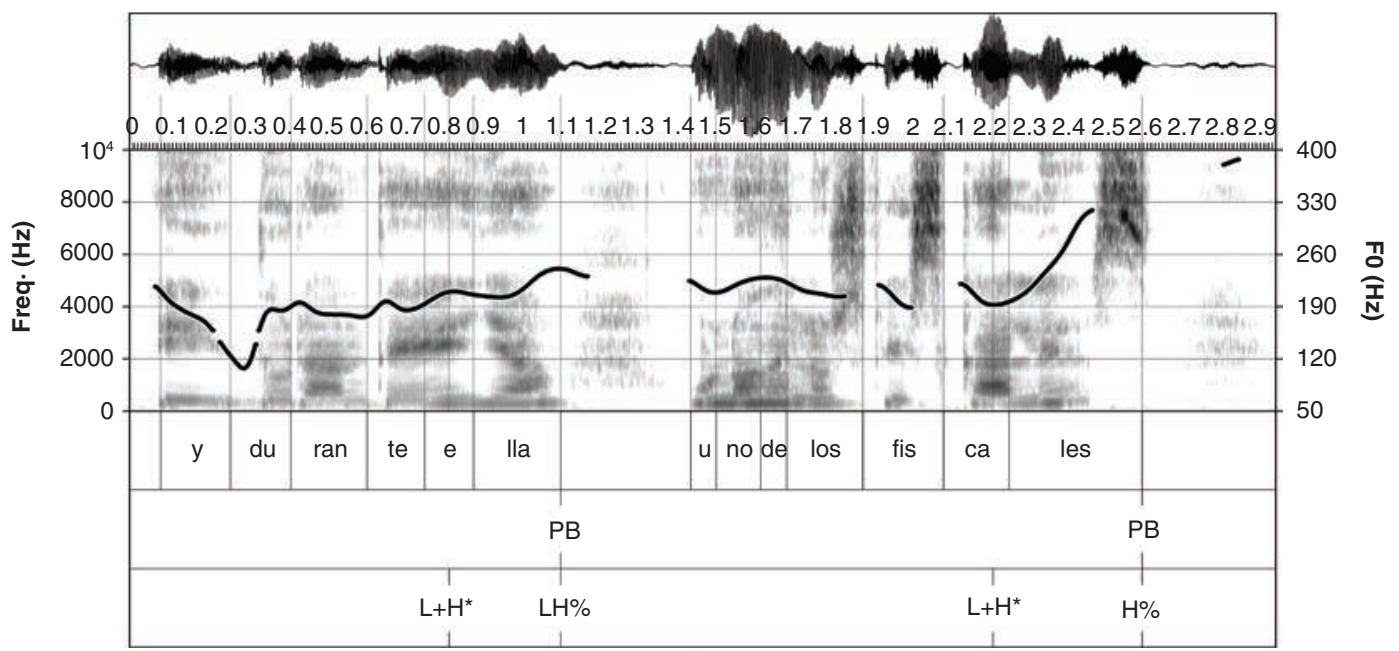


Figure 6: Example of final sustained pitch $\left(\mathrm{L}+\mathrm{H}^{*}=\%\right)$ for the phrase $y$ cincuenta mil pesetas de multa produced by SS4 in L1 Spanish.

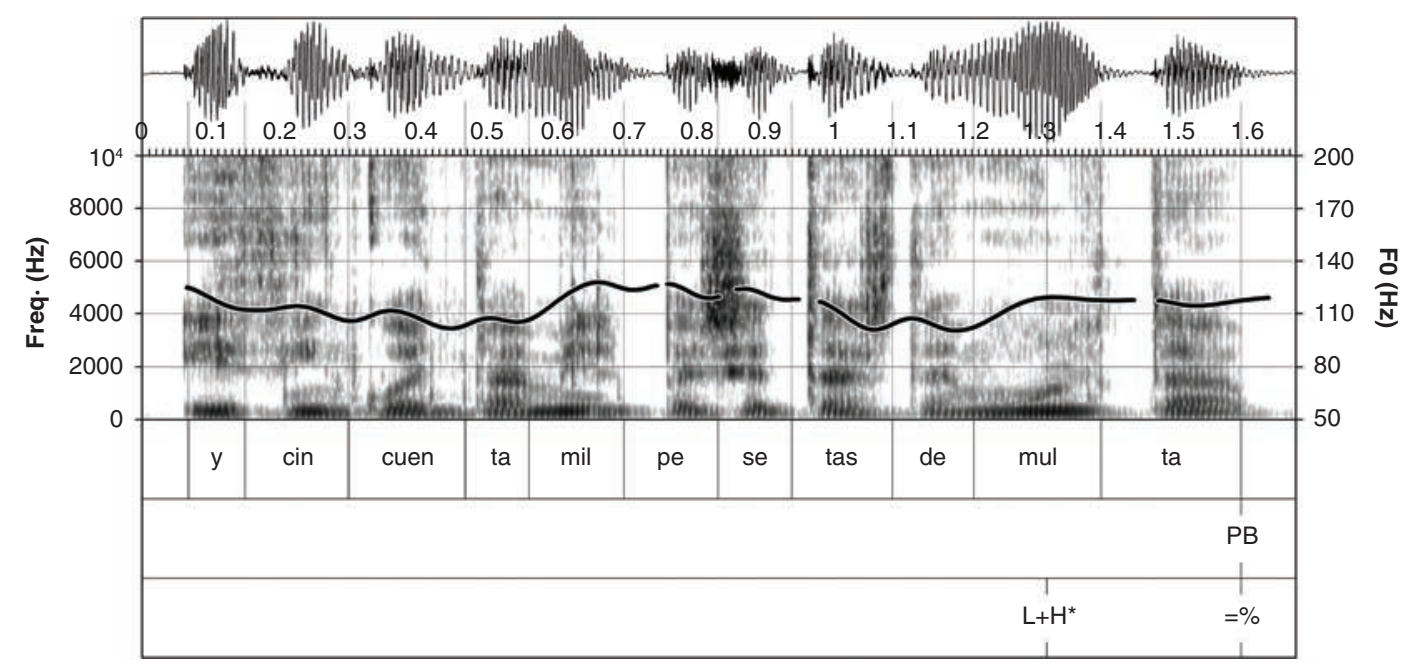

Table 5: Number of occurrences of the final tonal configurations produced by the six Spanish speakers in imitated Englishaccented Spanish (IEAS) in the protasis and the apodosis positions.

\begin{tabular}{|c|c|c|c|c|c|c|c|}
\hline \multirow[b]{3}{*}{ Sp } & \multicolumn{7}{|c|}{ Number of occurrences of the final tonal configurations in IEAS } \\
\hline & \multicolumn{5}{|c|}{ Protasis } & \multicolumn{2}{|c|}{ Apodosis } \\
\hline & $(\mathrm{L})+\mathrm{H} * \mathrm{H} \%$ & $(\mathrm{~L})+\mathrm{H}^{*} ! \mathrm{H} \%$ & $(\mathrm{~L})+\mathrm{H}^{*} \mathrm{LH} \%$ & $*=\%$ & $L^{*} \mathbf{L} \%$ & $L^{*} \mathbf{L} \%$ & $(\mathrm{~L})+\mathrm{H}^{*} \mathbf{L} \%$ \\
\hline SS1 & 29 & - & - & - & - & 4 & - \\
\hline SS2 & 26 & 1 & - & 1 & - & 4 & - \\
\hline SS3 & 27 & 2 & - & - & - & 4 & - \\
\hline SS4 & 15 & 2 & 8 & - & - & 4 & - \\
\hline SS5 & 16 & 1 & - & - & 2 & 4 & - \\
\hline SS6 & 16 & 1 & 8 & - & 1 & 4 & - \\
\hline All & 129 & 7 & 16 & 1 & 3 & 24 & - \\
\hline
\end{tabular}

The results also show four cases of $\mathrm{L}^{*} \mathrm{~L} \%$ in the protasis, which might be the result of an unexpected anticipation of a complete phrase. Thus, the most recurrent tonal structure for the declarative sentences produced in L1 Spanish is a rising pattern $\left((\mathrm{L})+\mathrm{H}^{*} \mathrm{H} \%\right)$ in the protasis position followed by a fall ( $\left.\mathrm{L}^{*} \mathrm{~L} \%\right)$ in the apodosis.

Table 5 displays the number of occurrences of the final tonal configurations produced by the six Spanish speakers in IEAS in the protasis and the apodosis positions.

As with L1 Spanish, all speakers used L* L\% in the apodosis with no instances of $\mathrm{L}+\mathrm{H}^{*} \mathrm{~L} \%$ when they produced IEAS. Thus, the typical low-fall of Spanish declaratives was also used in imitated English-accented Spanish. As before, the most recurrent $f_{0}$ pattern in the protasis was a rise $\mathrm{L}+\mathrm{H}^{*} \mathrm{H} \%$. Examples of the two patterns are displayed in Figure 7 for the utterance La vista oral|se celebró $\mid$ el miércoles pasado produced by SS2 in IEAS with two final rising contours in the protasis $\left(\mathrm{L}+\mathrm{H}^{*} \mathrm{H} \%\right)$ and a low-fall (L* L\%) in the apodosis.
The fall-rise pattern ( $\mathrm{L}+\mathrm{H}^{*} \mathrm{LH} \%$ ) was found in some of the productions of two speakers (SS4 and SS6). Figure 8 shows an example of the utterance uno de los fiscales|Carlos Valcárcel produced with two phrases with a final $\mathrm{L}+\mathrm{H}^{*} \mathrm{LH} \%$ by SS6 in IEAS.

All speakers, except for SS1, showed a few cases of a final fall-to-mid tone $\left((\mathrm{L})+\mathrm{H}^{*} ! \mathrm{H} \%\right)$. Figure 9 illustrates the utterance la vista oral| se celebró|el miércoles pasado|y durante ella produced by speaker SS4 in IEAS with three phrases ending with a rising pattern and the last one ending with a fall-to-mid configuration.

Finally, two speakers (SS5 and SS6) used the lowfall (L* L\%) typical of the apodosis in the protasis. As before, this seems to be due to wrong anticipation of a complete intonation phrase. Thus, similar to the L1 Spanish data, the most common tonal structure for the declarative sentences produced in IEAS involves a rising pattern $\left(\mathrm{L}+\mathrm{H}^{*} \mathrm{H} \%\right)$ in the protasis followed by a low-fall $(\mathrm{L} * \mathrm{~L} \%)$ in the apodosis. 
FigURE 7: Example of the utterance La vista oral| se celebró| el miércoles pasado produced by SS2 in imitated English-accented Spanish (IEAS), with two rising tonal patterns in the protasis $\left(\mathrm{L}+\mathrm{H}^{*} \mathrm{H}^{\%}\right)$ and a low-fall $\left(\mathrm{L}^{*} \mathrm{~L} \%\right)$ in the apodosis.

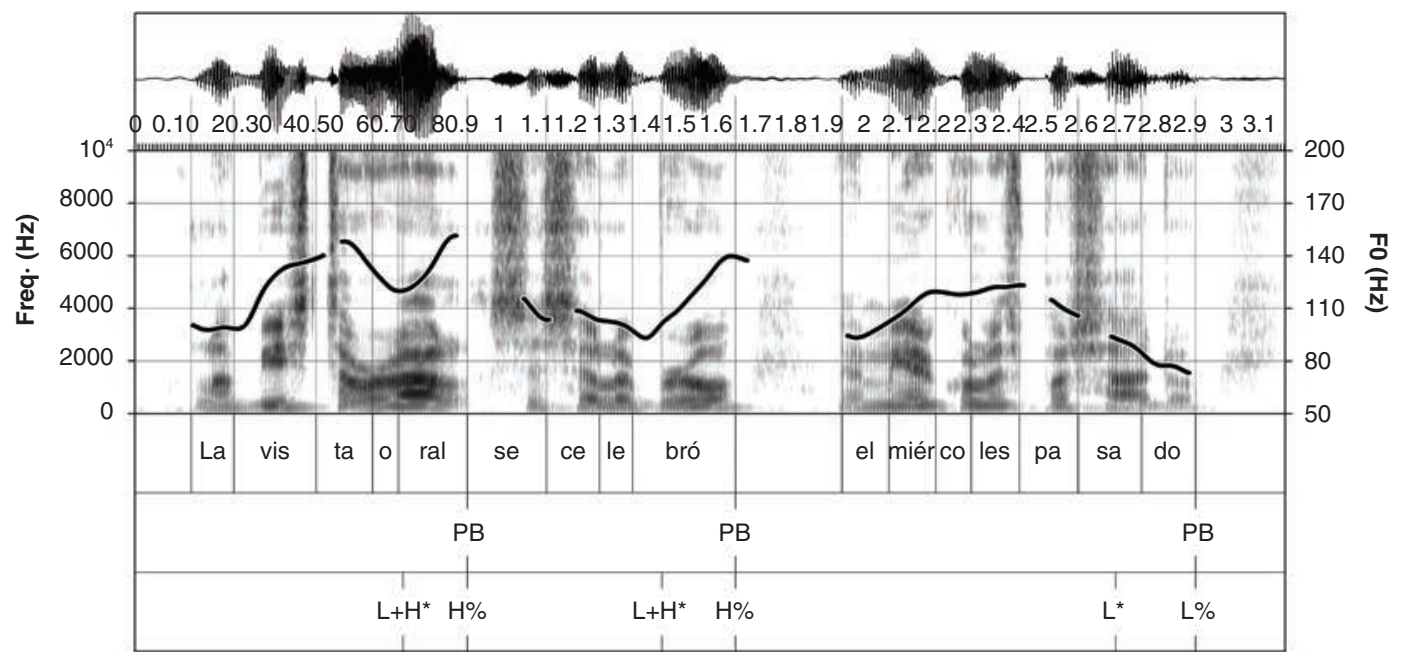

FigURE 8: Example of the utterance uno de los fiscales |Cárlos Valcárcel produced by SS6 in imitated English-accented Spanish (IEAS), with two fall-rise tonal configurations $\left(\mathrm{L}+\mathrm{H}^{*} \mathrm{LH} \%\right)$ in the protasis.

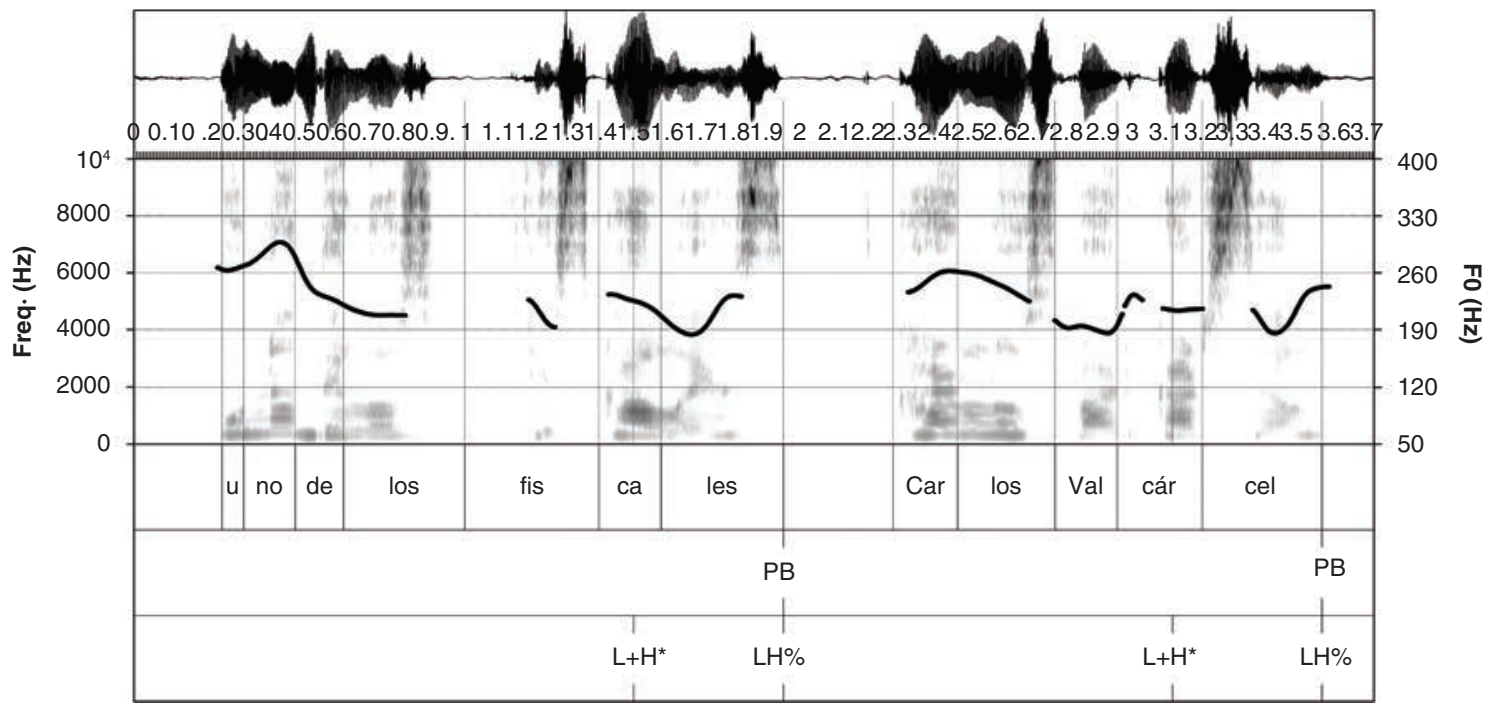

Tables 6 and 7 compare the percentage of occurrence of the tonal configurations in L1 Spanish and in IEAS in protasis and in apodosis positions respectively.

In order to verify whether the different reading conditions, namely, L1 Spanish versus IEAS, had any statistical effect on the frequency of occurrence of the different tonal structures, an analysis of contingency tables was carried out for the protasis position by means of a Pearson's Chi-square test and the analysis of the adjusted residual values. The results confirm that differences in the proportions between the two groups of speakers are generally not significant $\left(\chi^{2}=8.765 ; \mathrm{df}=4 ; p<0,067\right)$. Only for the fall-rise contour $\left((\mathrm{L})+\mathrm{H}^{*} \mathrm{LH} \%\right)$ the adjusted residual values show a significant lack of proportion indicating that it is more frequently used in IEAS than in L1.

According to these results, there is a clear usage of L1 Spanish intonation in the production of IEAS. The tones of the apodosis position are the same ones in the two reading conditions, whereas those of the protasis also show a similar behavior, being the rising contour $\left((\mathrm{L})+\mathrm{H}^{*} \mathrm{H} \%\right)$ the most recurrent tonal configuration. In IEAS, there is a small increase in the usage of the fallrise pattern in the protasis $(10.3 \%)$ as opposed to L1 Spanish (1.8\%). Thus, Spanish speakers tend to use their L1 intonation patterns when they produce a fake English accent in Spanish. 
FIGURE 9: Example of the utterance la vista oral $\mid$ se celebró $\mid$ el miércoles pasado $\mid y$ durante ella produced by SS4 in imitated English-accented Spanish (IEAS), with three phrases ending with a final rise ( $\left.\mathrm{L}+\mathrm{H}^{*} \mathrm{H} \%\right)$ and the final one ending with a fall-to-mid tone $\left(\mathrm{L}+\mathrm{H}^{*} ! \mathrm{H}^{\%} \%\right)$ in the protasis.

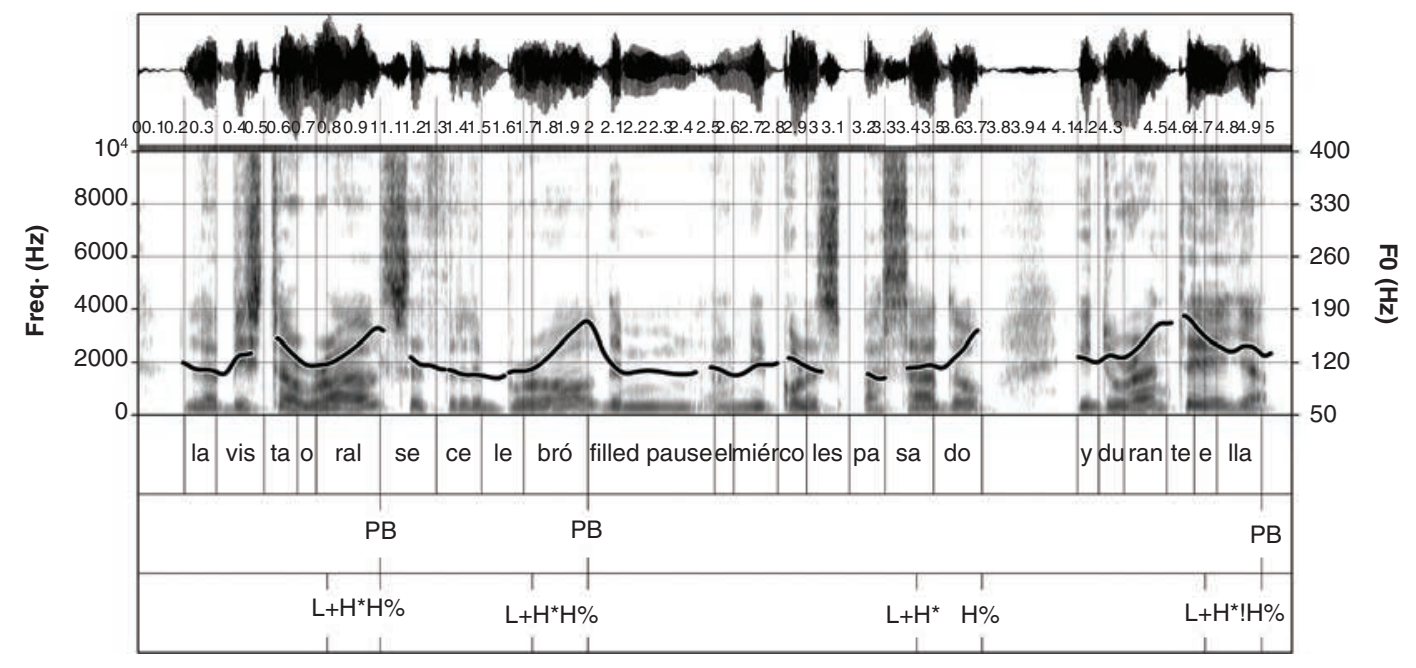

Table 6: Percentage of occurrence of the tonal configurations in protasis position in L1 Spanish and in imitated Englishaccented Spanish (IEAS).

\begin{tabular}{lcc}
\hline \multirow{2}{*}{$\begin{array}{l}\text { Tonal } \\
\text { configurations }\end{array}$} & \multicolumn{2}{c}{$\begin{array}{c}\text { Percentage of occurrence of } \\
\text { tones in protasis position }\end{array}$} \\
\cline { 2 - 3 }$(\mathrm{L})+\mathrm{H}^{*} \mathrm{H} \%$ & L1 Spanish & IEAS \\
$(\mathrm{L})+\mathrm{H}^{*} ! \mathrm{H} \%$ & 86.1 & 82.7 \\
$(\mathrm{~L})+\mathrm{H}^{*} \mathrm{LH} \%$ & 6.6 & 4.5 \\
$*=\%$ & 1.8 & 10.3 \\
$\mathrm{~L}^{*} \mathrm{~L} \%$ & 1.8 & 0.6 \\
\hline
\end{tabular}

Table 7: Percentage of occurrence of the tonal configurations in apodosis position in L1 Spanish and in imitated Englishaccented Spanish (IEAS).

\begin{tabular}{lcc}
\hline \multirow{2}{*}{$\begin{array}{l}\text { Tonal } \\
\text { configurations }\end{array}$} & \multicolumn{2}{c}{$\begin{array}{c}\text { Percentage of occurrence of } \\
\text { tones in apodosis position }\end{array}$} \\
\cline { 2 - 3 } $\mathrm{L}^{*} \mathrm{~L} \%$ & L1 Spanish & IEAS \\
$\mathrm{L}+\mathrm{H}^{*} \mathrm{~L} \%$ & 100 & 100 \\
\hline
\end{tabular}

\subsection{English speakers}

\subsubsection{Phrasing}

The text in (5) shows the places where a prosodic break was produced in authentic English-accented Spanish (AEAS) and the percentage of occurrence. The phrases marked in bold indicate that neither in L1 Spanish nor in IEAS there was a break in this position. Thus, only some English speakers produced a prosodic break after the phrases in bold.

(5) Authentic English-accented Spanish (AEAS)

01. El joyero $(100 \%) \mid$ Federico (25\%)|Vanero $(100 \%)$

02. ha sido condenado $(100 \%)$ | por la Audiencia de Santander $(100 \%)$

03. a ocho meses $(25 \%) \mid$ de arresto mayor (100\%) |

04. y cincuenta $\mathbf{( 2 5 \% )} \mid$ mil $(25 \%) \mid$ de multa $(100 \%)$

05. por un delito $(25 \%) \mid$ de compra de objetos robados. $(100 \%)$

06. La vista oral $(100 \%) \mid$ se celebró $(75 \%) \mid$ el miércoles pasado $(100 \%)$

07. y, (25\%) | durante ella, (100\%)|

08. uno de los fiscales, (75\%) $\mid$ Carlos Valcárcel, $(100 \%)$

09. pidió para el joyero $(66.6 \%) \mid$ tres años de prisión $(25 \%) \mid$ menor $(100 \%) \mid$

10. y una multa de cincuenta mil pesetas. $(100 \%)$

11. Gracias a las revelaciones de Vanero $(100 \%)$

12. de hace dos años $(75 \%) \mid$ y medio $(100 \%)$

13. se llegó (25\%) | a descubrir (50\%) | la existencia de una sospechosa mafia policial en España, $(100 \%)$

14. parte de la cual $(100 \%) \mid$ se vio envuelta $(25 \%) \mid$ en el llamado $(100 \%) \mid$

15. “caso $(25 \%) \mid$ el Nani”. (100\%)

The results in (5) show that in $98 \%$ of cases English speakers agree with Spanish speakers in the location of prosodic breaks. There are only four instances, corresponding to $2 \%$ of the total number of breaks, in which an intonation unit was produced in AEAS but not in L1 Spanish or IEAS. Most of these breaks, for instance, 
cincuenta|mil pesetas ("fifty|thousand pesetas") are rather unexpected because they split a syntactic phrase. All these unexpected prosodic breaks were produced by the same speaker (ES3), whose reading of the Spanish text showed more disfluencies or interruptions as compared to the productions of the other English speakers.

Table 8 exhibits the individual and the total number of occurrences of prosodic breaks produced by the English speakers. The mean value of prosodic breaks in AEAS is 27. This value is higher than the mean value of breaks is L1 Spanish (22) but slightly lower than the mean value of breaks in IEAS (30). Even though more data is needed to be able to draw more robust conclusions on the differences and similarities between AEAS and IEAS, this first approximation seems to indicate that in IEAS speakers tend to produce a few more prosodic breaks than in AEAS, suggesting a possible overdoing in the production of intonation units in the imitated accent.

Table 9 includes the percentage of agreement and disagreement in the production of prosodic breaks in AEAS. In $55.9 \%$ of the cases, all English speakers produced a prosodic break, whereas in $44.1 \%$ of the cases only some speakers produced a break.

These results are more similar to the behavior observed in IEAS (with $45 \%$ of agreement and $55 \%$ of disagreement in the location of prosodic breaks) than that detected in the L1 Spanish productions (with $69.5 \%$ of agreement and $30.5 \%$ of disagreement; see Table 3 ). This indicates that both in real and in imitated foreign accents the location of breaks is less consistent than in L1. Thus, according to these results, the division of a text into prosodic phrases might not be a reliable cue to distinguish a fake from a real foreign accent since there is a lot of variability in the location of prosodic breaks in both types of accents.

Table 8: Individual and total number and mean value of prosodic breaks produced by the English speakers in authentic English-accented Spanish (AEAS).

\begin{tabular}{lc}
\hline Speakers & $\begin{array}{c}\text { Number of prosodic } \\
\text { breaks in AEAS }\end{array}$ \\
\hline ES1 & 26 \\
ES2 & 27 \\
ES3 & 28 \\
ES4 & 27 \\
Total & 108 \\
Mean & 27 \\
\hline
\end{tabular}

Table 9: Percentage of (dis)agreement in the presence of a prosodic break (PB) in authentic English-accented Spanish (AEAS).

\begin{tabular}{lc}
\hline & AEAS \\
\hline \% of agreement in the location of a prosodic break & 55.9 \\
\% of disagreement in the location of a prosodic break & 44.1 \\
\hline
\end{tabular}

\subsubsection{Final tone configurations}

Table 10 displays the number of occurrences of the final tonal configurations produced by the four English speakers in real English-accented Spanish. As in Tables 4 and 5, the shaded boxes show the intonation patterns of the apodosis (or phrases that indicate a complete information) and the white boxes the tonal configurations of the protasis (or phrases that indicate non-finality).

As far as the tonal patterns for the apodosis are concerned, the productions in AEAS show more variability than those in L1 Spanish and in IEAS. As in the Spanish data, the most recurrent tonal configuration in the apodosis of the English productions was also a low-fall ( $\mathrm{L}^{*} \mathrm{~L} \%$ ). An example is provided in Figure 10 for the utterance La vista oral se celebró| el miércoles pasado produced by ES4. Whereas the first phrase (protasis) ends with a rising movement $\left(\mathrm{L}+\mathrm{H}^{*} \mathrm{H} \%\right)$, the second phrase (apodosis) is produced with $\mathrm{L}^{*} \mathrm{~L} \%$.

However, whereas all Spanish speakers, both in L1 Spanish and in IEAS, only produced the L* L\% configuration in the apodosis position, some English speakers also used a high-fall ((L)+H* $\mathrm{L} \%)$. The (L) $+\mathrm{H}^{*} \mathrm{~L} \%$ movement was also observed in the protasis of a few AEAS utterances. This is also different from the Spanish data, which showed no cases of $(\mathrm{L})+\mathrm{H}^{*} \mathrm{~L} \%$ in the protasis but a few instances of $\mathrm{L}^{*} \mathrm{~L} \%$ (see Tables 4 and 5). An example of two $(\mathrm{L})+\mathrm{H}^{*} \mathrm{~L} \%$ patterns in the protasis position are illustrated in Figure 11 for the utterance $y$ cincuenta mil pesetas $\mid$ de multa produced by ES4 in AEAS. As displayed in Figure 11, the $f_{0}$ peak of the $\mathrm{L}+! \mathrm{H}^{*}$ tone in the first phrase is downstepped with respect to the previous peak. The $\mathrm{L}+\mathrm{H}^{*}$ pitch accent of the second phrase is not marked as downstepped because it is not preceded by a peak within the same tone unit. However, the actual $f_{0}$ peak of this accent is not very high most probably due to a supradeclination effect, that is, the $f_{0}$ downtrend that does not affect single intonation units but a higher domain, such as the whole text (see Garrido, 1996, 1999, 2001).

Even though the productions with an $\mathrm{L}+\mathrm{H}^{*} \mathrm{~L} \%$ pattern in AEAS in the apodosis are minor in our data (see Tables 10 and 12), the usage of this tonal pattern in declarative sentences is very frequent in L1 English. Some scholars have actually classified the high-fall as the unmarked final pattern in statements (see O'Connor and Arnold, 1973, or Couper-Kuhlen, 1986) as opposed to the low-fall, which conveys a more detached, uninterested and even hostile nuance. Other phoneticians describe the final movement of English declaratives as a terminal fall (see Bolinger, 1978, or Cruttenden, 1986), or a definitive fall (Wells, 2006), which can be interpreted as a "merged" category between $\mathrm{L}^{*} \mathrm{~L} \%$ and $\mathrm{L}+\mathrm{H}^{*} \mathrm{~L} \%$.

The variability in the final falling movement found in AEAS is not present in L1 Spanish or in IEAS, which consistently show a final $\mathrm{L}^{*} \mathrm{~L} \%$ contour. The low-fall or cadencia $\left(\mathrm{L}^{*} \mathrm{~L} \%\right)$ has been considered the unmarked ending for Spanish declaratives since the very first studies on Spanish intonation (see Navarro Tomás, 1974 [1944]). On the other hand, $\mathrm{L}+\mathrm{H}^{*} \mathrm{~L} \%$ (or tono circunflejo in Navarro 
Table 10: Number of occurrences of the final tonal configurations produced by the four English speakers in authentic English-accented Spanish (AEAS).

\begin{tabular}{|c|c|c|c|c|c|c|c|}
\hline \multirow[b]{3}{*}{ Sp } & \multicolumn{7}{|c|}{ Number of occurrences of the final tonal configurations in AEAS } \\
\hline & \multicolumn{5}{|c|}{ Protasis } & \multicolumn{2}{|c|}{ Apodosis } \\
\hline & $(\mathrm{L})+\mathbf{H} * \mathbf{H} \%$ & $(\mathrm{~L})+\mathrm{H}^{*} ! \mathrm{H} \%$ & $(\mathrm{~L})+\mathbf{H} * \mathbf{L H} \%$ & $*=\%$ & $(\mathrm{~L})+\mathbf{H}^{*} \mathbf{L} \%$ & $\mathbf{L} * \mathbf{L} \%$ & $(\mathrm{~L})+\mathbf{H} * \mathbf{L} \%$ \\
\hline ES1 & 6 & 3 & 8 & 2 & 3 & 3 & 1 \\
\hline ES2 & 9 & 1 & 12 & - & 1 & 4 & - \\
\hline ES3 & 15 & 1 & 8 & - & - & 3 & 1 \\
\hline ES4 & 8 & 1 & 12 & - & 2 & 3 & 1 \\
\hline All & 38 & 6 & 40 & 2 & 6 & 13 & 3 \\
\hline
\end{tabular}

Figure 10: Examples of low fall $\left(\mathrm{L}^{*} \mathrm{~L} \%\right)$ at the end of the second phrase and a rise $\left(\mathrm{L}+\mathrm{H}^{*} \mathrm{H} \%\right)$ at the end of the first phrase for the utterance La vista oral se celebró| el miércoles pasado produced by ES4 in AEAS.

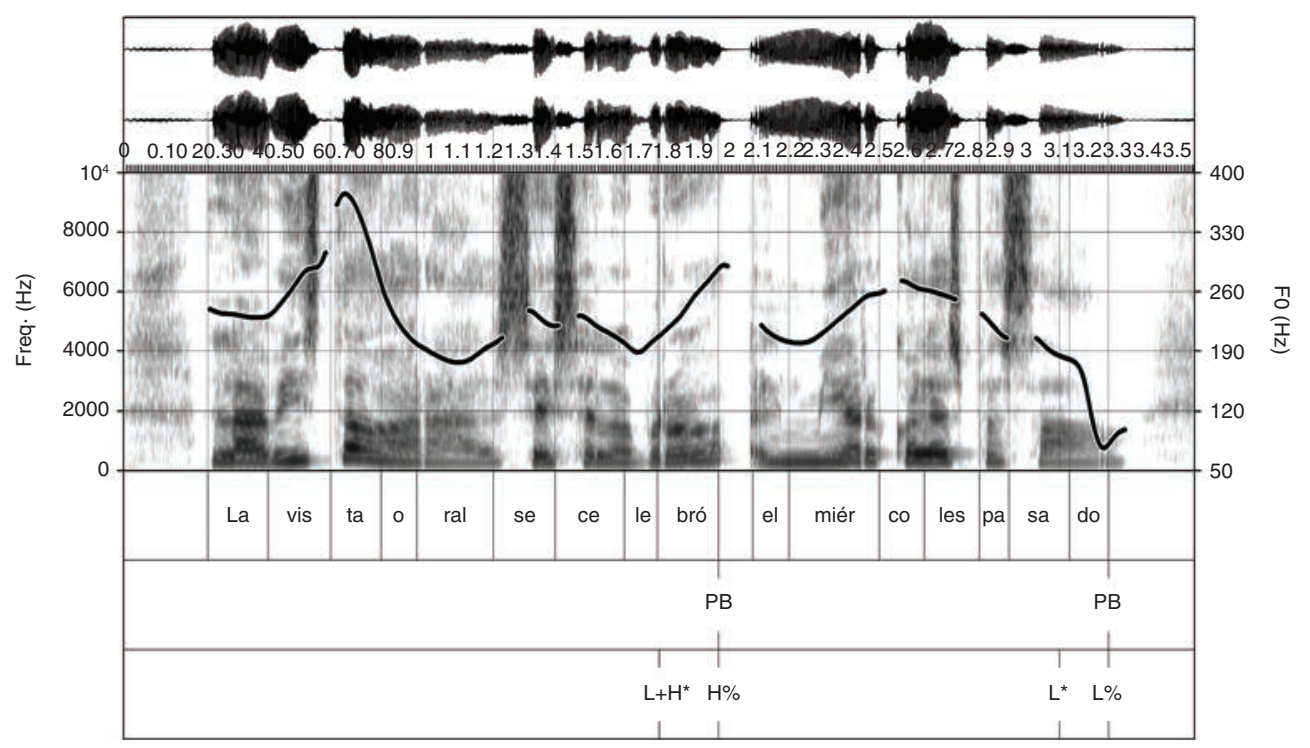

FigURE 11: Example of two high-fall patterns $\left(\mathrm{L}+\mathrm{H}^{*} \mathrm{~L} \%\right)$ in protasis position for the utterance $y$ cincuenta mil pesetas de multa produced by ES4 in authentic English-accented Spanish (AEAS).

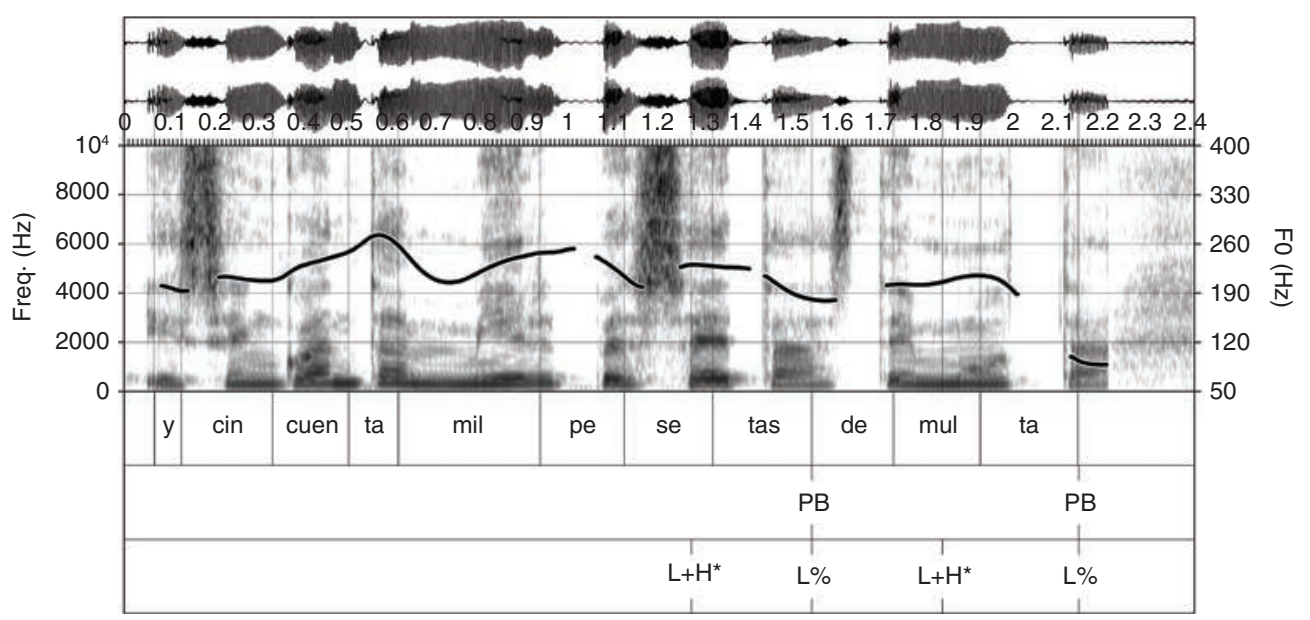


Tomás's terms), has been used to account for the final fall in contrastive or emphatic declaratives (see also EstebasVilaplana and Prieto Vives, 2008, or Prieto and Roseano, 2010, among others).

Thus, although at this point no clear conclusions can be reached from our data, given the reduced number of productions, the presence of both a high-fall $\left(\mathrm{L}+\mathrm{H}^{*} \mathrm{~L} \%\right)$ and a low-fall $\left(\mathrm{L}^{*} \mathrm{~L} \%\right)$ in the declarative sentences of AEAS suggests that this might be an issue to study further, since the variability in the production of the final accent in statements can be a helpful cue to distinguish real English-accented Spanish from a fake accent.

In the protasis, the productions of English speakers also presented more variability than those of the Spanish speakers. Whereas in L1 Spanish and in IEAS more than $80 \%$ of the final contours in the protasis were produced with a rise $\left(\mathrm{L}+\mathrm{H}^{*} \mathrm{H} \%\right.$; see Table 6$)$, in AEAS not only the rise $\left(\mathrm{L}+\mathrm{H}^{*} \mathrm{H} \%\right)$ but also the fall-rise $\left(\mathrm{L}+\mathrm{H}^{*} \mathrm{LH} \%\right)$ were used with a similar frequency of occurrence, i.e., $41.3 \%$ and $43.5 \%$ respectively (see Table 11 ). An example of $\mathrm{L}+\mathrm{H}^{*} \mathrm{H} \%$ can be observed in Figure 10. Figure 12 includes two instances of the $\mathrm{L}+\mathrm{H}^{*} \mathrm{LH} \%$ configuration for the utterance el joyero $\mid$ Federico Vanero produced by ES4 in AEAS.

Table 11: Percentage of occurrence of the tonal configurations in protasis position in authentic English-accented Spanish (AEAS).

\begin{tabular}{lc}
\hline Tonal configurations & $\begin{array}{c}\text { Percentage of occurrence of tones } \\
\text { in protasis position in AEAS }\end{array}$ \\
\hline (L) $+\mathrm{H}^{*} \mathrm{H} \%$ & 41.3 \\
$(\mathrm{~L})+\mathrm{H}^{*} ! \mathrm{H} \%$ & 6.5 \\
$(\mathrm{~L})+\mathrm{H}^{*} \mathrm{LH} \%$ & 43.5 \\
$*=\%$ & 2.2 \\
$(\mathrm{~L})+\mathrm{H}^{*} \mathrm{~L} \%$ & 6.5 \\
\hline
\end{tabular}

Finally, the fall-to-mid accent $\left(\mathrm{L}+\mathrm{H}^{*} ! \mathrm{H} \%\right)$ and the sustained tone $(*=\%)$ are used in a minority of cases in AEAS, namely, $6.5 \%$ and $2.2 \%$ respectively, as shown in Table 11 . The fall-to-mid pattern $\left(\mathrm{L}+\mathrm{H}^{*} ! \mathrm{H} \%\right)$ is illustrated at the end of the phrase displayed in Figure 13 for the utterance se llegó a descubrir produced by ES1.

The low occurrence of the fall-to-mid and the sustained patterns in AEAS is very similar to behavior observed in L1 Spanish and in IEAS. As exhibited in Table 6 , in L1 Spanish, the fall-to-mid pattern $\left(\mathrm{L}+\mathrm{H}^{*} ! \mathrm{H} \%\right)$ was used in $6.6 \%$ of the cases and the sustained tone $(*=\%)$ in $1.8 \%$. In IEAS, on the other hand, $\mathrm{L}+\mathrm{H}^{*} ! \mathrm{H} \%$ was used in $4.5 \%$ of the cases and $*=\%$ in $0.6 \%$. It is probable that in other types of speech, such as dialogues or conversations, these tonal patterns would be recurrent both in AEAS and in IEAS. As claimed in Estebas-Vilaplana et al. (2015), the sustained tone was the most recurrent configuration in the protasis position of conversational speech. Further research is needed on the usage of these tonal configurations in imitated accents in spontaneous speech.

Finally, the results of the statistical analysis comparing the frequency of occurrence of the tonal configurations found in IEAS and in AEAS in the protasis position confirm the different behavior observed in the two speech samples $\left(\chi^{2}=56.532 ; \mathrm{df}=5 ; p<0,001\right)$. The adjusted residual values show that, on the one hand, the proportion of $(\mathrm{L})+\mathrm{H}^{*} \mathrm{H} \%$ is significantly lower in

Table 12: Percentage of occurrence of the tonal configurations in apodosis position in authentic English-accented Spanish (AEAS).

\begin{tabular}{lc}
\hline Tonal configurations & $\begin{array}{c}\text { Percentage of occurrence of tones } \\
\text { in apodosis position in AEAS }\end{array}$ \\
\hline $\mathrm{L}^{*} \mathrm{~L} \%$ & 81.25 \\
$(\mathrm{~L})+\mathrm{H}^{*} \mathrm{~L} \%$ & 18.75 \\
\hline
\end{tabular}

FigURE 12: Example of two fall-rise patterns $\left(\mathrm{L}+\mathrm{H}^{*} \mathrm{LH} \%\right)$ in the protasis position for the utterance el joyero Federico Vanero produced by ES4 in authentic English-accented Spanish (AEAS).

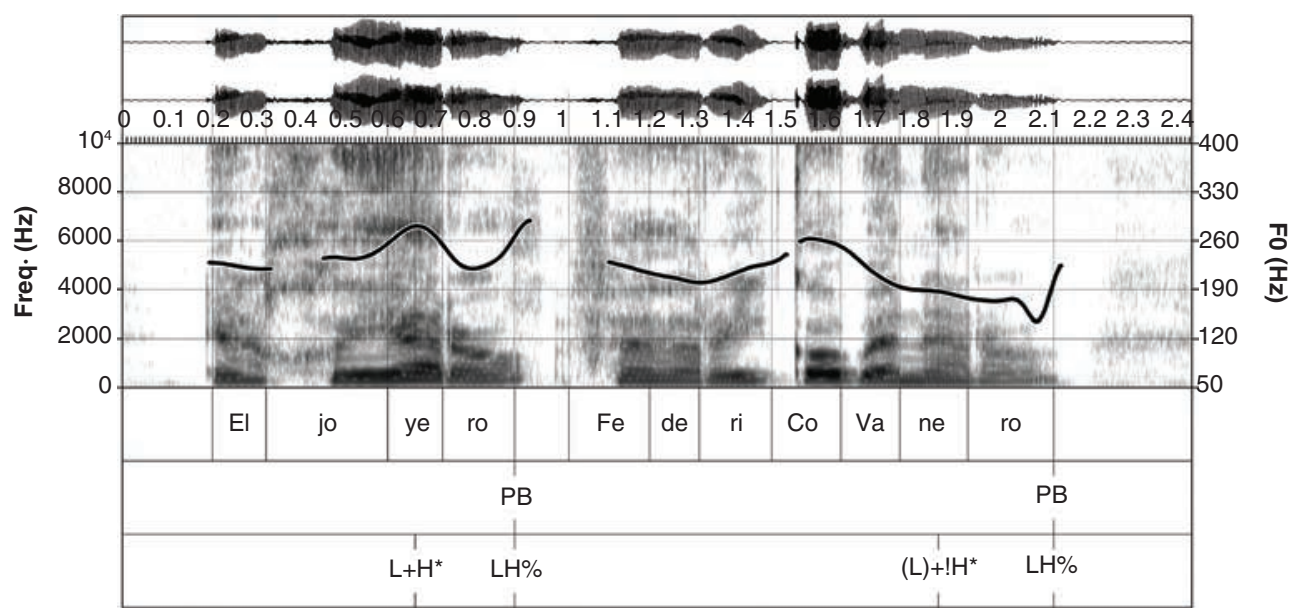


FigURE 13: Example of a fall-to-mid tonal configurations $\left(\mathrm{L}+\mathrm{H}^{*} ! \mathrm{H} \%\right)$ in protasis position for the utterance se llegó a descubrir produced by ES1 in authentic English-accented Spanish (AEAS).

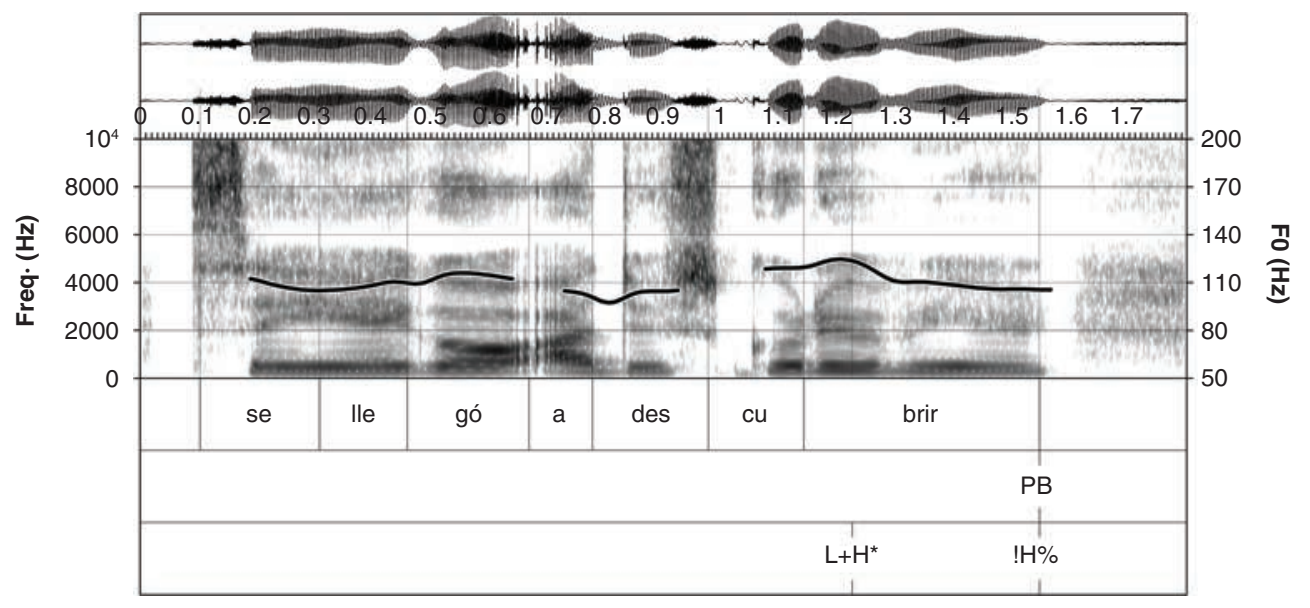

authentic English-accented Spanish than in the imitated accent (-6.7 vs. 6.7). On the other hand, the proportion of $(\mathrm{L})+\mathrm{H}^{*} \mathrm{LH} \%$ is higher than expected in AEAS on the basis of the null hypothesis of independence, confirming a significant higher frequency of occurrence of the fall-rise pattern in authentic English-accented Spanish as opposed to the imitated accent (adjusted residual values of 6 vs. -6). Finally, another pattern that also shows significant differences (3.2 vs. -3.2) is the high-fall contour $\left(\mathrm{L}+\mathrm{H}^{*} \mathrm{~L} \%\right)$ that is produced in AEAS but not in IEAS. The low-fall configuration ( $\mathrm{L}^{*} \mathrm{~L} \%$ ) only appears in IEAS but since it only occurs in $1.9 \%$ of the cases, the results of the statistical analysis are non-significant.

\section{DISCUSSION}

This study has compared the realization of some prosodic features in a corpus of read declarative sentences produced in L1 Spanish, in imitated English-accented Spanish (IEAS), and in authentic English-accented Spanish (AEAS). In particular, it has examined the main differences and similarities in the location of prosodic breaks and in the tonal categorization of the final or nuclear configuration of an intonation phrase, namely, the last pitch accent and the following boundary tone.

As far as phrasing is concerned, the results show a higher number of prosodic breaks in IEAS than in L1 Spanish. This seems to indicate that in imitated speech speakers may exaggerate some of their productions and overdo the number of prosodic breaks. The exaggeration in the production of phonetic features in imitated speech has been attested by some authors, such as Zetterholm (1997), who studied the imitation of the voice of Swedish politicians by other L1 Swedish speakers. She concluded that for a good impersonation it is important to exaggerate several typical features of the target speaker. EstebasVilaplana (2017a) also showed that Spanish speakers overproduced some intonation patterns when they spoke Spanish with an English accent. Thus, the higher number of prosodic breaks attested in IEAS as opposed to L1 Spanish may be the result of the overdoing effect found in imitation.

The comparison in the location of prosodic breaks in IEAS and in AEAS shows similar results, with a $90 \%$ of coincidence in the number of intonation units in the real and in the fake accents. The main reason for this high number of prosodic breaks in IEAS and in AEAS might be due to a different cause. Whereas in IEAS the increase in the number of intonation units might be related to a tendency towards exaggerating an imitated accent, in AEAS the high number of breaks may respond to the hesitation effects typical of a foreign accent (Reitbrecht $\&$ Hirschfeld, 2015). In any case, the similar number of prosodic breaks found in IEAS and AEAS indicates that phrasing is not a reliable cue to differentiate real Englishaccented Spanish from fake English-accented Spanish since it works very similarly in the two conditions.

The analysis of the tonal structure in the final configuration of phrases shows that Spanish speakers clearly adopt the Spanish intonation patterns of declarative sentences in their productions of IEAS. The typical falling pattern ( $\mathrm{L}^{*} \mathrm{~L} \%$ ) found in the apodosis of Spanish declaratives is transferred in their imitation of English-accented Spanish. This cue, however, is not decisive either to detect a fake accent, since English speakers also end declarative sentences with a fall. However, the results show that the final fall produced by English speakers presents more variability than the fall in the Spanish productions. Whereas Spanish speakers consistently produce a low-fall $\left(\mathrm{L}^{*} \mathrm{~L} \%\right)$ at the end of declarative sentences both in $\mathrm{L} 1$ Spanish and in IEAS, English speakers may also produce a high-fall $\left(\mathrm{L}+\mathrm{H}^{*} \mathrm{~L} \%\right)$. However, the occurrence of the high-fall pattern in the English data is not high enough to draw definite conclusions on its relevance to detect a fake accent and more investigation is needed on this issue.

The tonal configurations found in the protasis of both English and Spanish speakers show different patterns in the two languages. Whereas Spanish speakers produce a 
rising configuration $\left(\mathrm{L}+\mathrm{H}^{*} \mathrm{H} \%\right)$ in most of their productions both in L1 Spanish and in IEAS, English speakers show more variability and they use the rising contour $\left(\mathrm{L}+\mathrm{H}^{*} \mathrm{H} \%\right)$ along with the fall-rise $\left(\mathrm{L}+\mathrm{H}^{*} \mathrm{LH} \%\right)$ in fairly equal percentage of occurrences. This suggests that the recurrent presence of a fall-rise pattern in the protasis of declaratives may indicate that the English-accented Spanish is authentic. However, as before, we must be cautious with these generalizations because, even though the $\mathrm{L}+\mathrm{H}^{*} \mathrm{LH} \%$ tonal structure is less frequent in the protasis of Spanish declaratives than in the protasis of English sentences, the fall-rise is also possible in Spanish, as observed in our data and in other former studies (EstebasVilaplana et al., 2015).

Thus, our results suggest that the occurrence of a particular tonal configuration may not be a sufficient factor to detect the production of fake English-accented Spanish since the same tonal patterns have been observed in the productions of the two groups of speakers (in IEAS and AEAS). However, a more reliable cue seems to be found in the frequency of occurrence of a particular tonal structure, as in the case of the fall-rise pattern $\left(\mathrm{L}+\mathrm{H}^{*} \mathrm{LH} \%\right)$. Even though both English and Spanish speakers use this contour at the end of the protasis, the frequency of occurrence is much higher in real English-accented Spanish than in the fake productions. Figure 14 summarizes the percentage of occurrence of the different tonal configurations in the protasis in the three reading conditions (L1, IEAS, and AEAS).

Whereas the productions in L1 Spanish and in IEAS show a predominant use of the rising configuration $\left(\mathrm{L}+\mathrm{H}^{*} \mathrm{H} \%\right)$, those of AEAS indicate that both a rise pattern and a fall-rise pattern ( $\left.\mathrm{L}+\mathrm{H}^{*} \mathrm{LH} \%\right)$ are equally used in the protasis position. As stated in Wells (2006), the fall-rise pattern is very common in English intonation to convey non-finality and to indicate that the phrase that bears it is part of a higher structure. The results of this study are consistent with Wells' claim, since the fall-rise is the most recurrent pattern found in the protasis of AEAS. In the first descriptions of Spanish intonation,

FigURE 14: Percentage of occurrence of the tonal configurations in the protasis position in L1 Spanish, imitated English-accented Spanish (IEAS), and authentic English-accented Spanish (AEAS).

L1 spanish

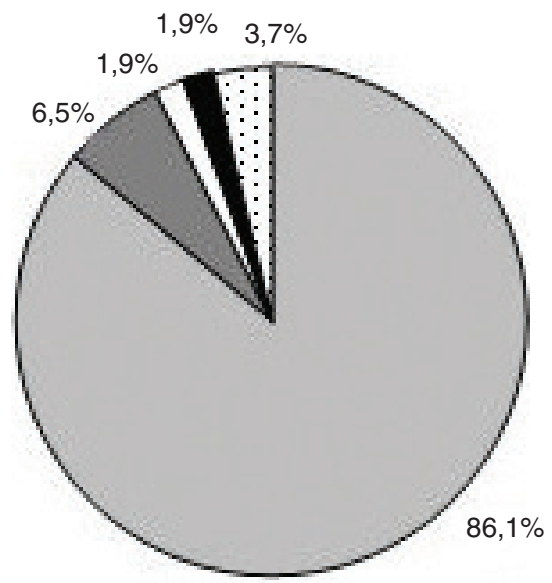

AEAS

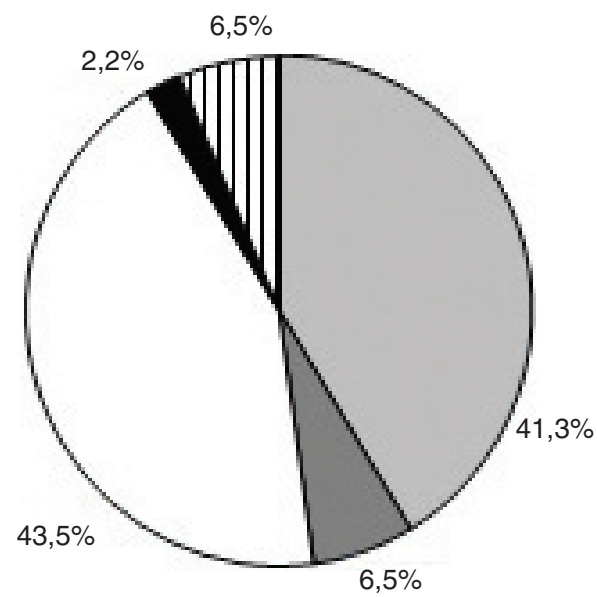

IEAS

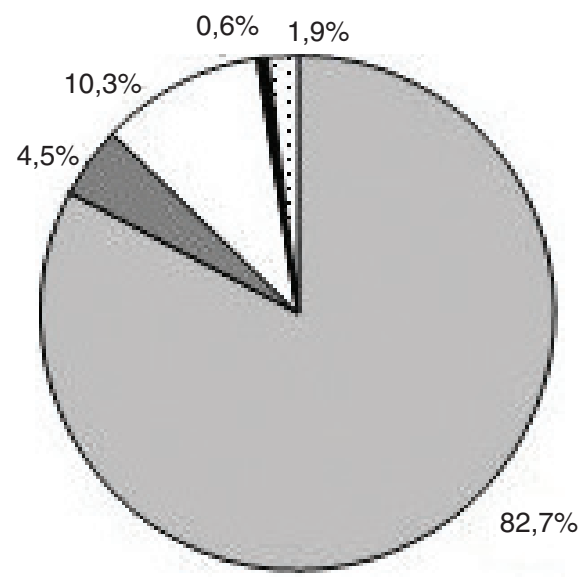

$(L)+\mathrm{H}^{*} \mathrm{H} \%$

$(\mathrm{L})+\mathrm{H}^{*} ! \mathrm{H} \%$

$(\mathrm{L})+\mathrm{H}^{*} \mathrm{LH} \%$

${ }^{*}=\%$

[. $L^{*} L \%$

D $(\mathrm{L})+\mathrm{H}^{*} \mathrm{~L} \%$ 
Navarro Tomás (1974 [1944]) also mentioned a fall-rise intonation in Spanish but he did not classify it as phonologically relevant. In Estebas-Vilaplana and Prieto Vives (2008), the fall-rise pattern ((L)+H* $\mathrm{LH} \%)$ was introduced in the tone inventory of Spanish since it proved to be contrastive to distinguish uncertainty statements from neutral statements. Estebas-Vilaplana et al. (2015) analyzed the presence of $\mathrm{L}+\mathrm{H}^{*} \mathrm{LH} \%$ in a read news corpus and in dialogues and found a moderate usage of this configuration in the protasis (14\% of cases). This is similar to the results found in our study, which show a low usage of $\mathrm{L}+\mathrm{H}^{*} \mathrm{LH} \%$ in L1 Spanish $(1.8 \%)$ and in IEAS $(10.3 \%)$, as opposed to AEAS (43.5\%). Thus, the higher percentage of occurrence of the fall-rise pattern in AEAS may be used as a cue to identify a real English accent in Spanish. Further research is needed with more speakers and speaking styles.

The other pattern in the protasis position that also presents significant differences between the English and the Spanish productions is the high-fall pattern $\left(\mathrm{L}+\mathrm{H}^{*} \mathrm{~L} \%\right)$, which occurs in $6.5 \%$ of the cases in AEAS but is not present in the Spanish data, neither in L1 Spanish nor in IEAS. Even though this pattern has been usually described as being typical of the apodosis (see O'Connor and Arnold, 1973; Cruttenden, 1986; Wells, 2006, among others), three out of four English speakers used it in the protasis in AEAS. This might be due to an incorrect anticipation of a complete intonation phrase, which prompted the appearance of the unexpected contour. However, for the detection of a fake foreign accent, more important than the location of the tonal structure is the actual presence of a configuration that is not frequent in Spanish. Even though extra data is needed to be able to draw more robust conclusions, the presence of a high-fall accentual structure in the authentic English-accented Spanish productions and the lack of this pattern in the imitated ones might be a cue to take into consideration in the identification of fake English-accented Spanish.

\section{CONCLUSIONS}

This paper has examined the phrasing and the tonal structure of the final configurations of declarative sentences in a read corpus produced by a group of Spanish speakers in L1 Spanish and in imitated English-accented Spanish (IEAS), and by a group of English speakers in authentic English-accented Spanish (AEAS). The results have shown that, as far as phrasing is concerned, there are differences in the presence of prosodic breaks between L1 Spanish and imitated English-accented Spanish. However, a comparable number of intonation phrases were produced in imitated and in real English-accented Spanish, indicating that phrasing does not seem to be a reliable cue to detect a fake accent. The type of final tonal configuration is not a definite cue either since both languages show similar $f_{0}$ patterns in the protasis and in the apodosis of declarative sentences. However, more relevant seems to be the frequency of occurrence of some of these tonal patterns. In particular, the number of productions of the fall-rise nuclear configuration $\left(\mathrm{L}+\mathrm{H}^{*} \mathrm{LH} \%\right)$ in the protasis of authentic English-accented Spanish is significantly higher than that of imitated English-accented Spanish. Thus, the regularity in the repetition of this accentual configuration may suggest the presence of a real English accent in Spanish. Finally, the presence of a high-fall configuration $\left(\mathrm{L}+\mathrm{H}^{*} \mathrm{~L} \%\right)$ in authentic English-accented Spanish and the lack of it in L1 Spanish and in imitated English-accented Spanish is another pattern that needs further investigation.

\section{ACKNOWLEDGMENTS}

Authors acknowledge funding from the Spanish Ministerio de Economía, Industria y Competitividad: EMULANDO (FFI2014-59848-C2-1-P).

\section{REFERENCES}

Alcina, J., \& Blecua J. M. (1975). Gramática española. Barcelona: Ariel.

Beckman, M. E., Díaz-Campos, M., McGory, J. T., \& Morgan, T. A. (2002). Intonation across Spanish, in the Tones and Break Indices framework. Probus, 14(1), 9-36. https://doi. org/10.1515/prbs.2002.008

Bruyninckx, M., Harmegnies, B., Llisterri, J., \& Poch-Olivé, D. (1994). Language-induced voice quality variability in bilinguals. Journal of Phonetics, 22(1), 19-31.

Cicres, J., \& Fernández Trinidad, M. (2017). Análisis de los sonidos fricativos en un corpus de acento no nativo disimulado. In V. Marrero Aguiar \& E. Estebas Vilaplana (Eds.), Tendencias actuales en fonética experimental. CIFE 2017 (pp. 308-312). UNED: Madrid.

Couper-Kuhlen, E. (1986). An Introduction to English prosody. London: Edward Arnold.

Cruttenden, A. (1986). Intonation. Cambridge: Cambridge University Press.

de-la-Mota, C., \& Rodero, E. (2011). La entonación en la información radiofónica. In A. Hidalgo Navarro, Y. Congosto Martín \& M. Quilis Merín (Eds.), El estudio de la prosodia en España en el siglo xxi: Perspectivas y. ámbitos (pp. 159-176). Facultat de Filologia, Traducció $i$ Comunicació, Universitat de València.

Estebas-Vilaplana, E. (2017a). Análisis de los rasgos prosódicos en el acento imitado: El caso de las enumeraciones. In V. Marrero Aguiar \& E. Estebas Vilaplana (Eds.), Tendencias actuales en fonética experimental. CIFE 2017 (pp. 116-120). UNED: Madrid.

Estebas-Vilaplana, E. (2017b). How imitation can help the acquisition of L2 pronunciation. In Proceedings of the Phonetics Teaching and Learning Conference 2018. London: University College London. 9-11 August. Retrieved from https://www.ucl.ac.uk/drupal/site_pals/sites/pals/files/ migrated-files/PTLC-Proceedings-2017.pdf

Estebas-Vilaplana, E., Gutiérrez, Y. M., Vizcaíno, F., \& Cabrera, M. (2015). Boundary tones in Spanish declaratives: Modelling sustained pitch. In The Scottish Consortium for ICPhS 2015 (Ed.), Proceedings of the 18th International Congress of Phonetic Sciences. Glasgow, UK: The University of Glasgow, paper number 196, 1-4. Retrieved from https:// www.internationalphoneticassociation.org/icphs-proceedings/ICPhS2015/Papers/ICPHS0196.pdf

Estebas Vilaplana, E., \& Prieto Vives, P. (2008). La notación prosódica del español: Una revisión del Sp_ToBI. Estudios de Fonética Experimental, 17, 263-283.

Face, T. L. (2007). The role of intonational cues in the perception of declaratives and absolute interrogatives in Castilian Spanish. Estudios de Fonética Experimental, 16, 185-225.

Garrido, J. M. (1996). Modelling Spanish intonation for text-tospeech applications ( $\mathrm{PhD}$ Thesis). Bellaterra: Universitat Autònoma de Barcelona. 
Garrido, J. M. (1999). El reajuste de F0 como marca fonética de límite entre unidades entonativas: Un estudio experimental. In Actas del Primer Congreso de Fonética Experimental (pp. 233-239). Tarragona: Universitat Rovira i Virgili / Barcelona: Universitat de Barcelona.

Garrido, J. M. (2001). La estructura de las curvas melódicas del español: Propuesta de modelización. Lingüística Española Actual, 23(2), 173-209.

Gibson, M., Blecua, B., \& Cicres, J. (2017). Are American English speakers better at distinguishing fake English accents in Spanish than native Spanish speakers? In M. Belz, S. Fuchs, S. Jannedy, C. Mooshammer, O. Rasskazova, \& M. Zygis (Eds.), Tagungsband der 13. Tagung Phonetik und Phonologie im deutschsprachigen Raum (P\&P 13). 28.-29. September 2017: Berlin.

Hualde, J. I., \& Prieto, P. (2015). Intonational variation in Spanish: European and American varieties. In S. Frota \& P. Prieto (Eds.), Intonation in Romance (pp. 350-391). Oxford: Oxford University Press. https://doi.org/10.1093/acprof: oso/9780199685332.003.0010

Künzel, H. J. (2000). Effects of voice disguise on speaking fundamental frequency. Forensic Linguistics, 7(2), 149-179. https://doi.org/10.1558/s1l.2000.7.2.149

Markham, D. (1999). Listeners and disguised voices: The imitation and perception of dialectal accent. Forensic Linguistics, 6(2), 289-299. https://doi.org/10.1558/sll.1999.6.2.289

Masthoff, H. (1996). A report on a voice disguise experiment. Forensic Linguistics, 3(1), 160-167. https://doi.org/10.1558/ ijsll.v3i1.160

Navarro Tomás, T. (1974 [1944]). Manual de entonación española. New York: Spanish Institute in the United States.

Neuhauser, S. (2008). Voice disguise using a foreign accent: Phonetic and linguistic variation. The International Journal of Speech, Language and the Law, 15(2), 131-159. https:// doi.org/10.1558/ijsll.v15i2.131

Neuhauser, S., \& Simpson, A. P. (2007). Imitated or authentic? Listeners' judgments of foreign accents. In J. Trouvain \& W. J. Barry (Eds.), Proceedings of the 16th International Congress of Phonetic Sciences (pp. 1805-1808). Saarbrücken.

O'Connor, J. D., \& Arnold, G. F. (1973). Intonation of colloquial English. London: Longman.

Prieto, P., \& Roseano, P. (Eds.) (2010). Transcription of intonation of the Spanish language. Munich: LINCOM Europa.

Quilis, A. (1993). Tratado de fonología y fonética españolas. Madrid: Gredos.

Rodman, R. D. (1998). Speaker recognition of disguised voices: A program for research. In Proceedings of the Consortium on Speech Technology in Conjunction with the Conference on Speaker by Man and Machine: Direction for Forensic Applications (pp. 9-22). Ankara, Turkey: COST 250.

Schoonmaker-Gates, E. (2012). Perception of foreign accent in Spanish by native and nonnative listeners: Investigating the role of VOT and speech rate (PhD dissertation). Bloomington, IN: Indiana University.

Storey, K. C. (1996). Constants in auditory and acoustic voice analysis in forensic speaker identification in cases of disguised voice. Recent Developments in Forensic Linguistics, 203-216.

Tate, D. A. (1979). Preliminary data on dialect in speech disguise. In H. Hollien \& P. Hollien (Eds.), Current Issues in the phonetic sciences (847-850). Amsterdam: John Benjamins.

Tench, P. (1996). The intonation systems of English. London: Cassell.

Wells, J. C. (2006). English Intonation: An introduction. Cambridge: Cambridge University Press. 